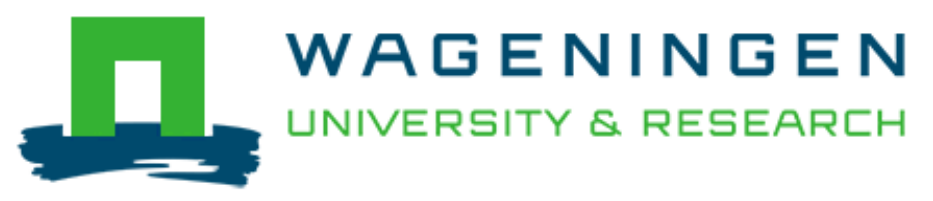

\title{
Decomposition of mixtures of cover crop residues increases microbial functional diversity
}

Drost, S. M., Rutgers, M., Wouterse, M., de Boer, W., \& Bodelier, P. L. E.

This is a "Post-Print" accepted manuscript, which has been Published in "Geoderma"

This version is distributed under a non-commercial no derivatives Creative Commons (c) 1 (1) $(9)$ (CC-BY-NC-ND) user license, which permits use, distribution, and reproduction in any medium, provided the original work is properly cited and not used for commercial purposes. Further, the restriction applies that if you remix, transform, or build upon the material, you may not distribute the modified material.

Please cite this publication as follows:

Drost, S. M., Rutgers, M., Wouterse, M., de Boer, W., \& Bodelier, P. L. E. (2019). Decomposition of mixtures of cover crop residues increases microbial functional diversity. Geoderma, [114060]. https://doi.org/10.1016/j.geoderma.2019.114060

You can download the published version at:

https://doi.org/10.1016/j.geoderma.2019.114060 
Decomposition of mixtures of cover crop residues increases microbial functional diversity

Sytske M. Drost ${ }^{1}$, Michiel Rutgers ${ }^{2}$, Marja Wouterse ${ }^{2}$, Wietse de Boer ${ }^{1,3}$, Paul L.E. Bodelier ${ }^{1}$

${ }^{1}$ Department of Microbial Ecology, Netherlands Institute of Ecology (NIOO-KNAW), Droevendaalsesteeg 10, 6708 PB Wageningen, The Netherlands

${ }^{2}$ Centrum Duurzaamheid, Milieu en Gezondheid, Rijksinstituut voor Volksgezondheid en Milieu (RIVM), Antonie van Leeuwenhoeklaan 9, 3721 MA Bilthoven, The Netherlands

${ }^{3}$ Chair group Soil Biology, Wageningen University and Research (WUR), Droevendaalsesteeg 3, 6708 PB Wageningen, The Netherlands

\section{Abstract:}

To improve sustainability in agricultural systems, winter cover crops are increasingly replacing fallow to stimulate soil functions that reduce nutrient losses and greenhouse gas production, reduce pests for the next cash crops, increase soil organic matter pools and reduce erosion. Several of these functions are highly dependent on soil microbes decomposing cover crop residues. Since cover crop species differ in their traits it is hypothesized that plant species residue mixtures with complementary characteristics perform better by stimulating soil microbial functional diversity. To test this, residues of cover crop monocultures and mixtures were mixed with agricultural soil in a microcosm experiment, and fungal and bacterial biomass, microbial metabolic potential, greenhouse gas emissions and soil nutrients were measured during 50 days. Fungal biomass increased for all treatments compared to the control (no additions). However, there were no significant differences between cover crop mixtures and monocultures. Biolog ECO plates were used as a proxy for the metabolic potential of the microbial community. The number of substrates used was significantly higher in soil amended with residues of cover crop mixtures indicating an increased number of substrate niches for microbes. C:N ratio of cover crop residues was shown to be an important variable in explaining dynamics of $\mathrm{CO}_{2}$ and $\mathrm{N}_{2} \mathrm{O}$ emissions. Mixtures of cover crops showed reduced $\mathrm{N}_{2} \mathrm{O}$ and $\mathrm{CO}_{2}$ emissions compared to monocultures at the start

Droevendaalsesteeg 10, 6708PB Wageningen

+31 (0)317473482

s.drost@nioo.knaw.nl 
of the experiment, but did not reduce greenhouse gas emissions over the whole incubation period. Adding nitrogen to the cover crop treatment with the highest C:N ratio (oat) did increase $\mathrm{N}_{2} \mathrm{O}$ emissions, but not $\mathrm{CO}_{2}$ emissions suggesting that decomposition rate of oat residues is not limited by nitrogen availability. Overall, mixtures of cover crops stimulated microbial functional diversity in soil incubations. Although this may have positive implications for soil quality and functioning in agricultural fields, further studies are needed to verify if these results hold under field conditions.

Keywords: microbial functional diversity, decomposition, cover crops, greenhouse gas emissions, sustainable agriculture

\section{INTRODUCTION}

Sustainable management of soils is essential to ensure balanced soil functioning with maintenance or increase of soil organic matter and minimal losses of inorganic nutrients, an idea already raised a few decades ago (Holmberg et al., 1991). Ecological processes such as decomposition are important for maintaining soil quality. These processes are modulated by soil biota, which are negatively affected by management in intensive agriculture (Tsiafouli et al., 2015) such as predominant use of mineral fertilizers and monoculture cropping systems. This reduces the functional diversity in the soil (Tsiafouli et al., 2015), which may affect plant performance. Creating more diverse cropping systems potentially leads to more sustainable agriculture as studies in (semi-)natural ecosystems have already shown that plant diversity improves soil microbial diversity leading to enhanced ecosystem functioning (Wardle et al., 2004; Fierer et al., 2009; Wagg et al., 2014; Lange et al., 2015). Additionally, it is known that high microbial diversity is important for maintaining multi-functionality in ecosystems (Eisenhauer et al., 2012; Wagg et al., 2014; Delgado-Baquerizo et al., 2016). By stimulating the microbial diversity, the aim is to increase functional diversity belowground such as the ability to metabolize a wide spectrum of organic compounds (metabolic potential). Diversification of organic matter inputs into agricultural systems, e.g. use of cover crop mixtures, is expected to increase functional diversity belowground (Hattenschwiler et al., 2005; Baumann et al., 2009). This can have positive effects on nutrient availability (Olson et al., 2010; Zhou et al., 2012) and suppression of pathogens (Wang et al., 2006). 
Cover crops grow during autumn and winter when the fields are usually fallow. During fallow, fields are more vulnerable to leaching of nutrients to groundwater. Cover crops can be harvested or are incorporated into the soil as green manure before the cash crops are introduced. This coincides with changes in the abundance and composition of microbes (Baumann et al., 2009; Shi and Marschner, 2014; Tao et al., 2017), being the biological catalysers of degradation. The compositional changes are related to the different substrates added to the soil (Baumann et al., 2009). However, the effects on functioning of the increased microbes are less clear.

Soil microbial functioning depends strongly on substrate quality and quantity (Mooshammer et al., 2014; Zechmeister-Boltenstern et al., 2015). Cover crops are usually fast growing species with a C:N ratio varying from 8 to 30 , delivering residues with an initial stoichiometry that deviates from that of the microbial biomass as the C:N ratio of the soil microbial biomass is on average 7 (Xu et al., 2013)). Mixtures with a wide range of plant species with deviating C:N ratios provide a range of substrates to the soil system, which may increase the niche breadth of the microbial community leading to an increased metabolic potential. For example, soil amended with residues composed of mixtures of plants with a wide range of chemical qualities resulted in additive effects for $\mathrm{C}$ and $\mathrm{N}$ mineralization (Redin et al., 2014). Besides $C$ and $N$, other nutrients like $P, S$ and $K$ can be provided by cover crop residues and these nutrients are important for microbial growth and activity (Tao et al., 2017). Furthermore, potassium concentrations are positively correlated with soil microbial biomass (Nair and Ngouajio, 2012). Hence, well-selected plant species mixtures may produce residues with a broader nutrient and stoichiometric spectrum thereby creating conditions facilitating the establishment of a diverse community with increased metabolic potential and higher microbial biomass compared to the use of monocultures (Nicolardot et al., 2007; Baumann et al., 2009; Baumann et al., 2011).

Besides nutrients released from plant residues, turnover of microbial biomass formed during degradation of cover crop residues, may contribute to nutrient supply for the main crop following cover crop residue decomposition. However, sparse information is available considering nutrient release from microbial biomass in soils. It has been demonstrated that microbial products released after decomposition are the main precursors of SOM formation (Cotrufo et al., 2013; Cotrufo et al., 2015; Kallenbach et al., 2016). Increases of SOM may be beneficial for plant growth by increasing the soil absorption complex and, therefore, nutrient retention (Lal, 2004; Lehmann and Kleber, 2015). SOM will only increase if the amount of carbon incorporation is higher than the carbon loss via respiration. 
Both litter quality (e.g. C:N ratio) and agricultural practices (tillage) influence greenhouse gas emissions after cover crop incorporation (Petersen et al., 2011; Abdalla et al., 2014; McCourty et al., 2018). Cover crop monocultures can have positive as well as negative effects on greenhouse gas emissions depending on the quality of the litter (Basche et al., 2014). It is expected that the microbial community will be more efficient in decomposing residue mixtures compared to monocultures (Bardgett and Shine, 1999; Loreau, 2001). The effects of mixtures of cover crops, on GHG emissions have still to be investigated.

In this study, we executed a pot experiment in which residues of cover crop monocultures and - mixtures were added to a sandy, intensively managed agricultural soil with the aim to test the following hypotheses:

- Microbial biomass is positively affected by mixtures of cover crop residues due to increased substrate diversity.

- Mixtures of residues lead to a higher microbial functional diversity by increasing the niche breadth of the microbial community.

- Residue mixtures reduce greenhouse gas emissions due to increased nutrient use efficiency.

\section{MATERIALS AND METHODS}

\subsection{Plant material and soil samples}

Cover crop material was harvested in February 2017 from plots created and managed by Joordens Zaden company in an arable field in Neer, the Netherlands $\left(51^{\circ} 18^{\prime} 24.7^{\prime \prime} \mathrm{N} 6^{\circ} 05^{\prime} 08.8^{\prime \prime E}\right)$. Harvest was one week before the cover crops were ploughed in. Above- and belowground plant material of fifteen species was harvested from five different plant families (Avena strigosa, Vicia sativa, Raphanus sativus, Guizotia abyssinica, Phacelia tanacetifolia, Sinapsis alba, Camelina sativa, Brassica carinata, Brassica napus, Lens culinaris, Medicago sativa, Pisum sativum, Trifolium alexantrinum, Secale cereale and Fagopyrum esculentum). These fifteen species represent commonly used cover crops in the Netherlands. All cover crops were harvested from monoculture fields. Roots were collected simultaneously with the shoots by first making the soil loose with a shovel before pulling the complete plants out of the soil. The cover crops were dried at $40^{\circ} \mathrm{C}$, cut in pieces of maximally $1 \mathrm{~cm}$ and stored at 
room temperature. Both above- and belowground plant material was used in the experiment (in ratio present at harvest and mixed during processing of the samples). Elemental composition (carbon (C), nitrogen $(\mathrm{N})$, phosphorus $(\mathrm{P})$, potassium $(\mathrm{K})$ and sodium $(\mathrm{S}))$ was analyzed. $\mathrm{C}$ and $\mathrm{N}$ was analyzed by grinding $1 \mathrm{mg}$ of plant material, transferred to tin cups and analyzed with an element analyzer (Flash EA 1112, Thermo Scientific). K, P and S were measured from $20 \mathrm{mg}$ of grinded plant material with microwave-assisted digestion with nitric acid and hydrogen peroxide (Hansen et al., 2009; Hansen et al., 2013) and measured on an ICP-OES (iCAP 6500 DUO, Thermo Scientific).

Soil was collected in April 2017 from a conventionally managed agricultural field in Wageningen, the Netherlands $\left(51^{\circ} 59^{\prime} 44.6^{\prime \prime} \mathrm{N} 5^{\circ} 39^{\prime} 34.9 " \mathrm{E}\right)$. The soil type is loamy sand ( $83 \%$ sand, $12 \%$ silt and $2 \%$ clay). This is a highly disturbed arenic gleysol. Soil pH was 5.3 and soil organic matter content $3.1 \%$. Prior to soil collection, the fields were from late summer after harvest of the cash crop (wheat). Fallow fields were used to ensure that the soil had no legacy of cover crops at the start of the experiment. The top $20 \mathrm{~cm}$ of the soil was collected, as this is the plowing depth of the field. Prior to the experiment, the soil was sieved through a $4 \mathrm{~mm}$ sieve to remove stones. The sieved soil was stored at $4^{\circ} \mathrm{C}$ before the start of the experiment for maximally 1 month.

\subsection{Experimental setup}

250 gram of moist soil was mixed with 0.5 gram of plant material of different combinations, cut in pieces of $1 \mathrm{~cm}$ in length, and added in small plastic pots made from HDPE $(6.5 \mathrm{~cm}$ in diameter and $14.5 \mathrm{~cm}$ height). The pots were loosely packed with a bulk density of $0.92 \mathrm{~g} / \mathrm{cm}^{3}$. The amount of added plant material is comparable with 5 ton per ha on an agricultural field scale, which is the common yield of cover crops in agriculture in the Netherlands. The treatments consisted of residues of monocultures of Avena strigosa (oat, A), Vicia sativa (vetch, V) and Raphanus sativus (radish, R), a three species mixture of vetch, radish and oat (VRA) and a 15 species mixture (15sp) containing all harvested cover crops. The plant material in the mixtures was equally divided among the species in the mixture $(0.17$ gram plant material per species in the 3 species mixture and 0.03 gram plant material per species in the 15 species mixture). The three monocultures and three species mixture were chosen as these three species are commonly used as cover crops, representing three different plant families. The 15 species mixture was used to create a highly diverse mixture of plant traits. The nutrient content of plant material in the different treatments is shown in Table 1. To identify if the microbial decomposing activity is nitrogen 
limited, a treatment with added mineral nitrogen was used in the monoculture with the highest C:N ratio (oat) $(\mathrm{A}+\mathrm{N})$. In this treatment, $37 \mathrm{mg} \mathrm{NH} \mathrm{NNO}_{3}$ was added to reduce the $\mathrm{C}: \mathrm{N}$ ratio to approximately 10 . As control (C), pots without added plant material were used.

The pots were incubated in the dark at $20^{\circ} \mathrm{C}$ for 50 days. The pots were watered twice a week to keep the water content of the soil at $60 \%$ of the water holding capacity ( $16.6 \mathrm{~g}$ water per $100 \mathrm{~g}$ of dry soil). Soil samples were taken at 1, 3, 7, 12 and 50 days after the start of the experiment. At the start (T0), a soil sample was taken before mixing plant residues with the soil. The subsamples were taken destructively to prevent disturbance of the pots. Soil samples were taken after mixing the soil in pots to obtain a homogeneous sample.

\subsection{Microbial biomass}

Fungal biomass was measured in one gram of soil for all sampling time points using ergosterol as a proxy following the Bååth alkaline ergosterol extraction method (Bååth, 2001; De Ridder-Duine et al., 2006). The ergosterol concentration was measured using LC-MSMS (6460 Triple Quad LC-MS, Agilent). Ergosterol was used to measure fungal biomass as this is a good method to estimate the saprotrophic fungi in the soil (Joergensen and Wichern, 2008). Bacterial biomass was measured using qPCR. DNA was extracted using DNeasy Powersoil Pro Kit (Qiagen, Venlo, The Netherlands) with 0.25 gram of soil according to the instructions provided by the supplier. The quantity and quality of the extracted DNA was analyzed with a spectrophotometer (Nanodrop 2000, Thermo Scientific). qPCR assays were used to target the $16 \mathrm{~S}$ rRNA gene for bacteria. Each assay was performed with $2 \mathrm{ng}^{*} \mu \mathrm{L}^{-1}$ of DNA in duplicates for each DNA extract with the primer pair EUB338 and EUB518 (Fierer et al., 2005). Each qPCR (total volume of $15 \mu \mathrm{L}$ ) consisted of $7.5 \mu \mathrm{L} 29$ SensiFAST SYBR (BIOLINE), $0.75 \mu \mathrm{L}$ of forward and reverse primes each, $1.5 \mu \mathrm{L}$ of bovine serum albumin ( $5 \mathrm{mg}^{*} \mathrm{~mL}^{-1}$; Invitrogen), $1.5 \mu \mathrm{L}$ DNase- and RNase-free water and $3 \mu \mathrm{L}$ of the template DNA. Standard curves were obtained using 10 -fold dilution series of a known amount of plasmid DNA from isolates of Collimonas ( $10^{8}$ to $10^{1}$ gene copies) containing the $16 \mathrm{~S}$ rRNA fragment. The qPCR was performed with a C1000 Touch Thermal Cycler (CFX-real-Time system, Bio-Rad Laboratories, Inc.). As negative control, water was used instead of template DNA. Efficiencies for all assays were between 80.3 and $112.1 \%$ with $r^{2}$ values between 0.951 and 0.989 .

Bacterial biomass $C$ was calculated by using the conversion factor 4.1 for $16 \mathrm{~s}$ rRNA gene copy numbers for bacteria (Santelli et al., 2008) and bacterial biomass estimates as described by Bloem et al. (1995). 
The ergosterol data were converted to fungal biomass $C$ using the conversion factor $5.4 \mathrm{mg}$ ergosterol*kg biomass $\mathrm{C}^{-1}$ (Klamer and Bååth, 2004). Both calculations were used to estimate the total microbial biomass $\mathrm{C}(\mathrm{MBC})$ in the soil and the fungi:bacteria ratio.

\subsection{Microbial functional diversity with Biolog ECO plates}

Biolog ECO plates (Biolog Inc., Hayward, CA) were used to determine the ability of the microbial community to grow on different substrates (metabolic potential). This is used as a proxy for microbial functional diversity and niche breadth of the community (Mallon et al., 2018). Biolog ECO plates contain 31 different C-substrates. To prepare Biolog ECO plates, microbial communities were extracted from 1 gram of soil with $10 \mathrm{ml}$ TrisBis buffer as described by Rutgers et al. (2016). The soil samples were taken at 12 and 50 days after the start of the experiment. Three dilutions (factor 8) from the microbial suspension were prepared based on a test sample to identify the transition point between low and high well color development to be able to distinguish the differences between the treatments. The ECO plates were incubated at $20^{\circ} \mathrm{C}$ in the dark under humid conditions. The absorbance at $592 \mathrm{~nm}$ (purple) and at $750 \mathrm{~nm}$ (turbidity) was measured at $2 \mathrm{~h}, 4 \mathrm{~h}$ and 3,5 and 7 days after plate preparation in a plate reader (Spectramax 250, Molecular Devices Corp., Memlo Park, CA). If the microbial community was able to grow on the substrate, absorbance $592 \mathrm{~nm}-750 \mathrm{~nm}$ of the substrate was higher than the blank (water) with a threshold of 0.1 , this was scored as "1". If there was no purple color development (no growth), this was scored with "0".

\subsection{Nutrient analyses}

At two time points (12 and 50 days), plant available soil nutrient concentrations ( $N, P, K$ and $\mathrm{S}$ ) were measured. $50 \mathrm{~mL} 1 \mathrm{M} \mathrm{KCl}$ was added to $10 \mathrm{~g}$ of soil to extract $\mathrm{NO}_{3}$ and $\mathrm{NH}_{4}$. Clear supernatant was stored in the freezer before analysis on an AutoAnalyzer (SEAL QuAAtro SFA system, Beun- de Ronde B.V. Abcoude, The Netherlands).

$\mathrm{P}, \mathrm{K}$ and $\mathrm{S}$ were determined after extraction of $3 \mathrm{~g}$ soil added to $30.0 \mathrm{~mL} 0.01 \mathrm{M}$ calcium chloride solution. This extraction procedure is used as it is considered as a proxy for plant available nutrients in the soil solution (Menzies et al., 2007). After 2 hours of shaking, the sample was centrifuged at $3000 \mathrm{rpm}$ and the supernatant was filtered through a Whatman Puradisc Aqua 30 filter with CA membrane. $130 \mu \mathrm{L}$ 
$\mathrm{HNO}_{3}$ was added to $12.87 \mathrm{ml}$ filtrate and stored for maximal one day at $4^{\circ} \mathrm{C}$ before analysis with an ICPOES (iCAP 6500 DUO, Thermo Scientific).

2.6 Greenhouse gas measurements

Greenhouse gas (GHG) fluxes were measured daily up to 9 days. From day 9 on, measurement frequency was decreased to once a week until the end of the experiment. Thus, measurements were done at days: $1-9,11,12,14,16,18,21,24,28,35,42$ and $50 . \mathrm{CO}_{2}$ and $\mathrm{N}_{2} \mathrm{O}$ fluxes were measured over an hour by closing the pots and taking an air sample at 0 and 60 min after closing. $20 \mathrm{~mL}$ of air was taken from the pots of which $14 \mathrm{ml}$ was flushed in a $6 \mathrm{~mL}$ exetainer (Labco, UK) and the last $6 \mathrm{~mL}$ was used to create an overpressure of 1 bar. The exetainers were analyzed using an autosampler (TriPlus RSH, Thermo Fisher Scientific, Bleiswijk, The Netherlands) connected to a gas chromatograph (GC1300, Thermo Fisher Scientific) equipped with a Methanizer and a Flame Ionization Detector (FID) to detect $\mathrm{CO}_{2}$ and $\mathrm{CH}_{4}$ an electron capture detector (ECD) for detection of $\mathrm{N}_{2} \mathrm{O}$. The gas chromatograph contained two sets of a pair Rt-Q-Bond capillary columns (L; 15m and 30m, ID; 0.53mm, Restek, Interscience, Breda, The Netherlands). Chromeleon ${ }^{\text {TM }}$ Chromatography Data System 7.1 (CDS, Thermo Fisher Scientific) software was used to analyze the obtained gas chromatograms from the GC. Fluxes of $\mathrm{CO}_{2}$ and $\mathrm{N}_{2} \mathrm{O}$ were calculated on basis of the accumulation during 1 hour. Gas concentrations were calculated in ppm values by comparing with calibration curves, which were generated by dilution of a certified gas mixture ( 1 ppm N $2 \mathrm{O}, 2$ ppm CH 4 and 2000 ppm CO 2 ; Linde Gas, The Netherlands). The concentrations (ppm) were converted into absolute amounts $(\mathrm{mmol})$ with the gas law: $p V=n R T$ in which $\mathrm{p}$ is the pressure in the pot, $\mathrm{V}$ is the volume, $\mathrm{n}$ is the amount gas in mol, $\mathrm{R}$ is the gas constant ( 8.31 $\mathrm{J} \cdot \mathrm{K}^{-1} \mathrm{~mol}^{-1}$ ) and $\mathrm{T}$ is the temperature. Cumulative fluxes of the $\mathrm{GHG}$ emissions were calculated by assuming that the time between the samples was similar to the average of both samples:

$$
\text { Cumulative flux }(\Phi)=\Phi_{T_{1}}+T_{j-i} *\left(0.5 * \Phi_{T_{i}}+0.5 * \Phi_{T_{j}}\right)+\cdots
$$
where $\Phi$ is the flux at time point $i$ and $T$ is the time between the different time points ( $i$ and $j)$.

\subsection{Data analysis}

The data were analyzed with $\mathrm{R}$ (version 3.5.1) with attached packages: agricolae, car and plyr for statistical analysis; ggplot2, grid and gridExtra for making figures; dplyr, survival, Formula and Hmisc for making correlation tables; and klaR and MASS for RDA analysis. First, the data were tested for normality 
and for homogeneity of variances. If this was not the case, Tukey's ladder of powers transformation in the package Rcompanion was used to meet the criteria for parametric statistical testing as log transformation was not sufficient to make the data normally distributed. The data were analyzed for significant treatment effects using a linear model and Anova. A post hoc Tukey test was used to identify the significant differences between the treatments. The greenhouse gas emissions data over time were not normally distributed and were analyzed using Kruskal-Wallis rank sum test combined with Scheffe test to determine treatment and time effects. Correlations were calculated between the GHG and nutrient content in the plant residues and in the soil.

The Biolog data were analyzed in R and Canoco (version 5). RDA analysis in Canoco was used to find the dissimilarity between the treatments. To determine if microbial biomass was driving differences in well color development, these parameters were added in the RDA analysis as environmental variables. All environmental variables were included in the analysis for visualization of the effecs. 500 permutations were used. Correlations were tested between the environmental variables.

Comparison of the effect of mixing of cover crops was done for the three species mixture. First, the expected values for contribution by the 3 species were determined by calculating the sum of all individual monocultures for a certain trait divided by the amount of species in the three species mixture. Next, it was tested if the values for the traits in the three species mixture were significantly different from the expected values. Results were statistical significant when the p-value was smaller than 0.05 .

\section{RESULTS}

\subsection{Microbial biomass}

Addition of plant material stimulated growth of fungi as indicated by increased soil ergosterol contents (Figure 1). The fungal biomass was not significantly different between the different residue treatments, but was higher than the control treatment $(C)$ without added plant residues $(p<0.001)$. There was no significant difference between the different time points (Table S1, $p=0.42$ ). Residue mixtures (VRA and 15sp) did not have an additive effect over monocultures, but mixtures showed a more gradual increase of ergosterol in the soil compared to the monocultures. Monocultures led to a fungal biomass peak at different time points, for example: vetch $(\mathrm{V})$ at 3 days and oat $(\mathrm{A})$ at 12 days. 
Bacterial biomass (based on 16S rRNA gene copy numbers) was significantly different between cover crops additions three days after cover crop incorporation (Figure 2, $p<0.001$ ). At this time point, radish $(R)$, vetch alone and the three species mixture (VRA) led to an increase of the bacterial biomass compared to the control. Overall vetch, radish and both mixtures led to an increase of bacteria during the experiment compared to the other treatments, which disappeared after 50 days of incubation. Dynamics of bacterial and fungal biomass development differed between treatments. Vetch led to an early increase of both fungal and bacterial biomass (at three days) while the oat residue led to an increase at a later time point (12 days). Mixtures had a more gradual increase and decrease and not a clear peak at one of the measured time points. Microbial biomass $\mathrm{C}(\mathrm{MBC})$ was calculated to estimate the total amount of microbial biomass in the soil. The MBC ranged between 0.45 to $28 \mathrm{mg} \mathrm{C}$ per $\mathrm{kg}$ soil (Table S3). The highest values for radish monoculture and the three species mixture were mainly driven by high bacterial abundance in the samples compared to the other treatments. The F:B ratio increased during decomposition, after 50 days, this increase disappeared (Table S3).

\subsection{Microbial functional diversity}

Microbial metabolic potential, as proxy for functional diversity, was measured with Biolog-ECO plates. Microbes in soil suspensions obtained from mixed residue additions showed a significant increase in substrate use compared to those obtained from monocultures at both time points (Figure 3 and Figure $S 1, p=0.0016$ ), except for vetch residue. For radish and oat (with and without added $N$ ), there was no significant difference compared to the control. Recalcitrant substrates like D-cellobiose (G1) and glycogen (F1) could be used at low concentrations by microbes derived from the mixtures of residues, while microbes from monocultures only degraded these substrates at the highest inoculum density. These differences between substrate use are shown in a RDA analysis (Figure 4). Radish, oat and oat with $\mathrm{N}$ grouped together, while $15 \mathrm{sp}$ and VRA are significantly different from vetch (V). Both mixtures could use several substrates including polymers and carboxylic acids while microbes from vetchamended soil used more amino acids. Microbial biomass had no significant effect on substrate use in the Biolog plate $(p=0.44)$. Only $C, 15 s p$ and $V$ explained a significant part of the variation observed in the redundancy analysis using forward selection (Table S8, adjusted P-values are lower than 0.05). 


\subsection{Greenhouse gas fluxes}

Cover crop addition to the soil showed an immediate response of greenhouse gas emissions. For all treatments, the first measurement at day 1 showed the highest GHG emissions. Vetch-amended soil showed the highest peak for both $\mathrm{CO}_{2}$ and $\mathrm{N}_{2} \mathrm{O}$ at the start followed by reduction that was faster than for the other residue treatments (Figure 5).

Cumulative fluxes showed that after 50 days, vetch decomposition resulted in the highest $\mathrm{N}_{2} \mathrm{O}$ emissions while oat (with the highest C:N ratio) had the lowest (Figure S2B). Based on the average greenhouse gas emissions of the three monoculture treatments, expected values for the three species mixture were calculated. The $\mathrm{N}_{2} \mathrm{O}$ emissions of the three species mixture was not significantly different from the expected $\mathrm{N}_{2} \mathrm{O}$ emissions. Cumulative $\mathrm{N}_{2} \mathrm{O}$ fluxes were negatively correlated with the C:N ratio of the initial plant material (Figure $S 4, r=-0.57, p=0.0014$ ), plant and soil $\mathrm{N}$ content correlated positively with $\mathrm{N}_{2} \mathrm{O}$ emissions $(r=-0.67, p<0.001$ and $r=-0.61, p<0.001$ respectively).

$\mathrm{CO}_{2}$ emissions showed a similar trend as $\mathrm{N}_{2} \mathrm{O}$ (Figure $5 \mathrm{~A}$ ). For vetch- and radish amendments there was a decrease during prolonged incubation, while $\mathrm{CO}_{2}$ fluxes for oat and oat with $\mathrm{N}$ were nearly constant over the experimental period. Cumulative $\mathrm{CO}_{2}$ emissions did not correlate with $\mathrm{C}: \mathrm{N}$ ratio of the residues $(r-0.16, p=0.40)$, but did correlate negatively with $C$ content $(r=-0.37, p=0.049), C: P(r=-$ $0.66, p<0.001)$ and $\mathrm{N}: \mathrm{P}$ ratio $(r=-0.57, \mathrm{p}=0.0016)$. Interestingly, $\mathrm{CO}_{2}$ emissions did correlate positively with initial plant $P(r=0.73, p<0.001), K(r=0.71, p<0.001)$ and $S(r=0.70, p<0.001)$ content and soil $K(r=0.71, p<0.001)$ and $S(r=0.65, p<0.001)$ content after 50 days (Figure S4).

The total global warming potential (GWP) was calculated based on the global warming potential for each separate gas from the cumulative fluxes over 50 days of incubation $\left(\mathrm{CO}_{2}=1\right.$ and $\left.\mathrm{N}_{2} \mathrm{O}=265\right)$. Overall, cumulative greenhouse gas fluxes showed that amendment with vetch and radish only resulted in the highest greenhouse gas emissions after 50 days (Figure 6).

\subsection{Soil nutrients}

Plant-available soil nutrient content was differently affected by cover crop residue additions. For $\mathrm{N}$, only $\mathrm{NO}_{3}{ }^{-}$content significantly accumulated in the soil during decomposition (Figure $7 \mathrm{~A}$ ). The materials with the lowest $\mathrm{C}: \mathrm{N}$ ratio (vetch) showed the largest mineral $\mathrm{N}$ accumulation at both time points. Oat alone immobilized $\mathrm{N}$ from the soil. Both mixtures show intermediate accumulation of mineral nitrogen in the 
soil. Mineral $\mathrm{N}$ accumulation for the three species mixture was similar to the expected value based on the three monocultures.

Both vetch and radish have high $S$ contents (Table 1). This is reflected by the extractable $S$ content in the soil after incubation at both 12 and 51 days after incubation (Figure S3C). Similar to S, vetch led to the highest extractable $\mathrm{K}$ and $\mathrm{P}$ content in soil as well (Figure S3A and B). Oat with added $\mathrm{N}$ had a significantly higher $\mathrm{P}$ increase over time than oat alone. The plant species mixtures had significantly higher concentrations of all three nutrients compared to oat, but not compared to the other two monocultures. Most of the $\mathrm{K}$ in the plant material was already available in the soil after 12 days. Approximately $90 \%$ of the $\mathrm{K}$ in the plant material was released for vetch, radish and the three species mixtures (Figure $8 \mathrm{~A}$ ), while only $5 \%$ of the $\mathrm{P}$ present in the total amount of residue (Figure $9 \mathrm{~B}$ ) and $50 \%$ of the added residue $\mathrm{S}$ was released in vetch and radish (Figure $8 \mathrm{C}$ ), as measured with $\mathrm{CaCl}_{2}$ extraction. Decomposing oat residues showed the lowest increase of mineral nutrients in the soil.

The amount of nutrients in the plant material added to the soil correlates positively with the nutrient content in the soil at the end of the experiment (Figure S4). The amount of $\mathrm{P}, \mathrm{K}$ and $\mathrm{S}$ in the plant strongly correlates with each other not only in the plant residue $(r>0.9, p<0.001)$, but also in the soil after 50 days $(r>0.48, p<0.01)$. Furthermore, the C:N, C:P and N:P ratio of the added cover crop residues correlates negatively with the amount of $\mathrm{K}, \mathrm{P}$ and $\mathrm{S}$ in the plant residue and in the soil.

\section{DISCUSSION}

We investigated the effect of soil amendment with cover crop residues of mixtures and of monocultures on respiration, mineralization, greenhouse gas emission and microbial functional diversity. As previously shown, above- and belowground biodiversity is important to maintain ecosystem functioning (Wagg et al., 2014). The current study aimed to determine if application of mixtures of cover crop residues has a positive effect on the functioning of soil microbes, compared to the residue of a monoculture cover crop. In this study, soil without a cover crop legacy was used to prevent effects of cover crops growing in the field (e.g. presence of root fragments). The cover crop residue amount used in this experiment is comparable to biomass production of winter cover crops. Although different cover crops in mixed cultures in the field do not produce the same amount of biomass, we used equal amounts of each species in the added mixtures to be able to identify if diversity effects could occur. 


\subsection{Microbial biomass dynamics}

Fungal and bacterial biomass did increase when cover crop residues were added to the soil (Figure 1 \& 2). The dynamics of fungal and bacterial biomass differed between residues added, which appeared to be mainly caused by C:N ratio of the plant residues. These results partially support the first hypothesis: different cover crop species can indeed lead to different microbial biomass dynamics. Mixtures of cover crop residues, however, did not result in increased biomass as compared to those of single species. Similar results have been published by Shi and Marschner (2014) who found only increased microbial activity, but no increased microbial growth in residue mixtures of root and shoot of a diverse set of plants as compared to either root or shoot residues alone. Furthermore, litter mixture effects in forests are mainly caused by the plant species identity (Hattenschwiler and Gasser, 2005) and do not lead to increased biomass of the decomposer community (Wardle et al., 2006). These studies show that increase in microbial biomass also depends on the residue mixture, amount of residue and the environment.

\subsection{Microbial functional diversity}

Mixing plant material might lead to an increased amount of substrate niches that can lead to increased microbial functional diversity in the soil. In this experiment, the metabolic response of the microbial community as assessed by Biolog Eco plates was influenced by cover crop residue additions. As hypothesized, mixtures led to increased functional diversity as compared to monocultures leading to increased metabolic potential of the community (Figure 4). It should be considered that Biolog ECO plates, in potential, do reflect the substrate usage of the aerobic carbon utilizing microbial community. Dormant and microbes with another physiology are not captured. However, the substrate range of the ECO plates is so broad that a wide range of microbes will be detected, wide enough to assess effects of changes in environmental conditions in microbial functioning in comparative experimental designs. Hence, Biolog can be used as indicator of microbial potential for substrate usage and potential changes therein as the results of the changes in physical chemistry (i.e. niches) of the soil. For natural systems, it was already shown that litter mixtures increase soil microbial diversity (Wardle et al., 2006; Chapman and Newman, 2010; Chapman et al., 2013; Byrnes et al., 2014; Delgado-Baquerizo et al., 2016). Several studies indicate that microbial functional diversity is enhancing soil ecosystem 
functions such as disease suppression (Van Elsas et al., 2002; Garbeva et al., 2006; Postma et al., 2008; Mallon et al., 2015b), decomposition and nutrient cycling (Wagg et al., 2014; Delgado-Baquerizo et al., 2016; Delgado-Baquerizo et al., 2017). Van Elsas et al. (2012) showed that a higher microbial diversity could lead to reduced ability for pathogens to invade soil environments. This may be a result of the higher competition for resources in diverse microbial communities with a more diverse metabolic potential leading to reduced niche space for the invader (Mallon et al., 2015a; Mallon et al., 2018). As with disease suppression, decomposition may need a functional diverse community to be able to decompose residues faster and use the nutrients more efficiently (Loreau, 2001; Hattenschwiler et al., 2005). This does not necessary mean that the microbial biomass is higher as well, as this experiment showed increased functional diversity, but not increased microbial biomass in mixtures compared to monocultures.

396

\subsection{Greenhouse gas emissions}

We hypothesized that residue mixtures lead to reduced GHG emissions compared to monocultures as we expected that the microbial community would be more efficient in using nutrients in residue mixtures compared to monocultures as a result of increased carbon use efficiency (Hattenschwiler et al., 2005). In this experiment, mixtures did not reduce cumulative GHG emissions compared to residues from monocultures (Figure 6). Vetch had the highest cumulative emissions. The nitrogen concentration in the vetch residue was nearly double compared to the other residues (Table 1). This may have increased the decomposability of the vetch compared to the other residue treatments. Management practices, including cover crops and tillage, play an important role in mitigating GHG emissions (Kallenbach et al., 2010; Abdalla et al., 2012; Abdalla et al., 2014). Furthermore, as shown by Basche et al. (2014) in a meta-analysis, decomposition of cover crops led to increased $\mathrm{N}_{2} \mathrm{O}$ emissions, mainly caused by the amount of $\mathrm{N}$ added with cover crops. This shows that nutrient content of the plant material is a main driver of soil GHG fluxes and microbial activity in the soil (Basche et al., 2014; Marschner et al., 2015; Nguyen et al., 2016). In the current study, the total amount of plant material was the same for all treatments, leading to different amounts of $\mathrm{C}$ and other nutrients added to the soil (Table 1) leading to correlations between the amount of $\mathrm{C}$ and $\mathrm{N}$ and greenhouse gas emissions. The correlation between the amount of $\mathrm{C}$ and $\mathrm{CO}_{2}$ emissions was weaker compared to the amount of $\mathrm{N}$ with $\mathrm{N}_{2} \mathrm{O}$ emissions, probably because the 
amount of $\mathrm{C}$ is not only important but also the recalcitrance of the material. Furthermore, adding $\mathrm{N}$ in the treatment with oat residue did increase mainly $\mathrm{N}_{2} \mathrm{O}$ emissions but not $\mathrm{CO}_{2}$ emissions. This lack of response in respiration may be explained by the recalcitrance of the material to degradation or shortage of other nutrients.

\subsection{Nutrient release}

The impact of decomposing cover crop residues on nutrient availability depended on the plant species, as shown in the results (Figure $7 \& 8$ ). $\mathrm{K}$ availability in the soil increased up to $90 \%$ of the amount added with the plant material while $\mathrm{P}$ availability only increased up to $10 \%$. The available $\mathrm{P}$ released from the cover crops residues is low compared to a field study by Cobo et al. (2008) where only $30 \%$ of $\mathrm{N}$ and $\mathrm{P}$ remained in the plant material after 50 days of decomposition of two different leguminous plants. Rapid release of $\mathrm{K}$ from decomposing plant material has been shown earlier (Cobo et al., 2002). Decomposition of oat was not stimulated by the addition of $\mathrm{NH}_{4} \mathrm{NO}_{3}$, as the $\mathrm{CO}_{2}$ emissions (respiration rate) are similar to oat without added $\mathrm{N}$. The question arises: by what factor are these microbes limited other than N? Are other nutrients, e.g. P, K or S, missing? As shown before, adding nitrogen to decomposing plant residues can increase, decrease or have no effect on decomposition rates (Liu et al., 2006; Hobbie, 2008; Norris et al., 2013). In this experiment, the treatment with highest $\mathrm{N}$ content, vetch, led to an increase of the fungal biomass quickly after start of the experiment and higher $\mathrm{CO}_{2}$ emissions, but vetch also had higher $\mathrm{P}, \mathrm{K}$ and $\mathrm{S}$ amounts in the plant residues. Microbes may lack these nutrients in the treatment where only $\mathrm{N}$ was added to oat. Interestingly, $\mathrm{P}$ availability in the soil is increased when $\mathrm{NH}_{4} \mathrm{NO}_{3}$ is added, indicating that other nutrients are limiting. $\mathrm{N}$ addition to decomposing litter in other systems led to increased P availability as well (Liu et al., 2006; Zhong et al., 2017). These results show that nutrient content in residues at the start of the experiment is a major driver for decomposition and nutrient release (Sakala et al., 2000; Partey et al., 2014; Marschner et al., 2015). Microbial activity might be important for the incorporation of plant derived carbon and nutrients in soil organic matter (SOM). In this experiment, the microbial biomass ranged between 0.45 to $28 \mathrm{mg} \mathrm{C}$ per $\mathrm{kg}$ soil. Microbes can mobilize nutrients during decomposition of plant residues, but also as a result of turnover of the microbial biomass. In this experiment, the nutrient concentration in the soil mainly increased during the first two weeks. As shown by Achat et al. (2010), microbial P is important in the P cycling and availability of $\mathrm{P}$ for plants. The available $\mathrm{P}$ is mainly present in the microbial community and 
this $\mathrm{P}$ has a short turnover time of only a few days (Achat et al., 2010). Thus, even though the microbial biomass represents a small portion of the soil, it can have large influence on nutrient availability.

\section{Conclusion}

In this study, decomposition of mixtures of cover crops and monocultures resulted in differences in dynamics of microbial biomass and functional diversity. The microbial biomass development in mixtures was more gradual as compared to monocultures. Furthermore, the microbial community became more functionally diverse in mixtures as shown by a higher ability to degrade substrates in Biolog ECO plates. Mixtures of residues did not increase GHG emissions and nutrient availability compared to the average of the monocultures. Overall, these results show that adding residue mixtures can lead to more balanced soil functioning. Further studies should test whether the microbial community will be more diverse in the field when using cover crop mixtures instead of monocultures to test if these microcosm results can be extrapolated to field conditions. This will help to determine how long this microbial community will be positively changed due to residues of cover crop mixtures.

\section{ACKNOWLEDGEMENTS}

We thank Iris Chardon and Hans Zweers for technical assistance. We thank Phillipe Packbier (Joordens, The Netherlands) for providing the cover crop residues. This study is part of the clever cover cropping project. This project is a collaboration between the Soil Biology Group (SBL-WU), the Centre for Crop Systems Analysis (CSA-WU), the Centre for Soil Ecology and the Netherlands Institute of Ecology (NIOO-KNAW) funded by the Netherlands Science Foundation NWO (project number 870.15 .073 ) with co-financing from companies (Agrifirm, Vandinter Semo, P.H. Petersen Saatzucht, and Joordens). This publication is publication number 6839 of the Netherlands Institute of Ecology (NIOO-KNAW).

\section{REFERENCES}

Abdalla, M., Hastings, A., Helmy, M., Prescher, A., Osborne, B., Lanigan, G., Forristal, D., Killi, D., Maratha, P., Williams, M., Rueangritsarakul, K., Smith, P., Nolan, P., Jones, M.B., 2014. Assessing the combined use of 
reduced tillage and cover crops for mitigating greenhouse gas emissions from arable ecosystem. Geoderma 223, 9-20.

Abdalla, M., Rueangritsarakul, K., Jones, M., Osborne, B., Helmy, M., Roth, B., Burke, J., Nolan, P., Smith, P., Williams, M., 2012. How Effective is Reduced Tillage-Cover Crop Management in Reducing N2O Fluxes from Arable Crop Soils? Water Air and Soil Pollution 223, 5155-5174.

Achat, D.L., Morel, C., Bakker, M.R., Augusto, L., Pellerin, S., Gallet-Budynek, A., Gonzalez, M., 2010. Assessing turnover of microbial biomass phosphorus: Combination of an isotopic dilution method with a mass balance model. Soil Biology and Biochemistry 42, 2231-2240.

Bååth, E., 2001. Estimation of fungal growth rates in soil using 14C-acetate incorporation into ergosterol. Soil Biology and Biochemistry 33, 2011-2018.

Bardgett, R.D., Shine, A., 1999. Linkages between plant litter diversity, soil microbial biomass and ecosystem function in temperate grasslands. Soil Biology and Biochemistry 31, 317-321.

Basche, A.D., Miguez, F.E., Kaspar, T.C., Castellano, M.J., 2014. Do cover crops increase or decrease nitrous oxide emissions? A meta-analysis. J. Soil Water Conserv. 69, 471-482.

Baumann, K., Marschner, P., Kuhn, T.K., Smernik, R.J., Baldock, J.A., 2011. Microbial community structure and residue chemistry during decomposition of shoots and roots of young and mature wheat (Triticum aestivum L.) in sand. European Journal of Soil Science 62, 666-675.

Baumann, K., Marschner, P., Smernik, R.J., Baldock, J.A., 2009. Residue chemistry and microbial community structure during decomposition of eucalypt, wheat and vetch residues. Soil Biology and Biochemistry 41, 1966 1975.

Bloem, J., Veninga, M., Shepherd, J., 1995. Fully automatic determination of soil bacterium numbers, cell volumes, and frequencies of dividing cells by confocal laser scanning microscopy and image analysis. Applied and Environmental Microbiology 61, 926-936.

Byrnes, J.E.K., Gamfeldt, L., Isbell, F., Lefcheck, J.S., Griffin, J.N., Hector, A., Cardinale, B.J., Hooper, D.U., Dee, L.E., Emmett Duffy, J., Freckleton, R., 2014. Investigating the relationship between biodiversity and ecosystem multifunctionality: challenges and solutions. Methods in Ecology and Evolution 5, 111-124.

Chapman, S.K., Newman, G.S., 2010. Biodiversity at the plant-soil interface: microbial abundance and community structure respond to litter mixing. Oecologia 162, 763-769.

Chapman, S.K., Newman, G.S., Hart, S.C., Schweitzer, J.A., Koch, G.W., 2013. Leaf Litter Mixtures Alter Microbial Community Development: Mechanisms for Non-Additive Effects in Litter Decomposition. Plos One 8, 9.

Cobo, J.G., Barrios, E., Delve, R., 2008. Decomposition and nutrient release from intra-specific mixtures of legume plant materials. Communications in Soil Science and Plant Analysis 39, 616-625.

Cobo, J.G., Barrios, E., Kass, D.C.L., Thomas, R.J., 2002. Decomposition and nutrient release by green manures in a tropical hillside agroecosystem. Plant and Soil 240, 331-342. 
Cotrufo, M.F., Soong, J.L., Horton, A.J., Campbell, E.E., Haddix, Michelle L., Wall, D.H., Parton, W.J., 2015. Formation of soil organic matter via biochemical and physical pathways of litter mass loss. Nature Geoscience 8, 776-779.

Cotrufo, M.F., Wallenstein, M.D., Boot, C.M., Denef, K., Paul, E., 2013. The Microbial Efficiency-Matrix Stabilization (MEMS) framework integrates plant litter decomposition with soil organic matter stabilization: do labile plant inputs form stable soil organic matter? Glob Chang Biol 19, 988-995.

De Ridder-Duine, A.S., Smant, W., Van der Wal, A., Van Veen, J.A., De Boer, W., 2006. Evaluation of a simple, non-alkaline extraction protocol to quantify soil ergosterol. Pedobiologia 50, 293-300.

Delgado-Baquerizo, M., Maestre, F.T., Reich, P.B., Jeffries, T.C., Gaitan, J.J., Encinar, D., Berdugo, M., Campbell, C.D., Singh, B.K., 2016. Microbial diversity drives multifunctionality in terrestrial ecosystems. Nat. Commun. $7,8$.

Delgado-Baquerizo, M., Trivedi, P., Trivedi, C., Eldridge, D.J., Reich, P.B., Jeffries, T.C., Singh, B.K., Bennett, A., 2017. Microbial richness and composition independently drive soil multifunctionality. Functional Ecology 31 , 2330-2343.

Eisenhauer, N., Reich, P.B., Isbell, F., 2012. Decomposer diversity and identity influence plant diversity effects on ecosystem functioning. Ecology 93, 2227-2240.

Fierer, N., Jackson, J.A., Vilgalys, R., Jackson, R.B., 2005. Assessment of Soil Microbial Community Structure by Use of Taxon-Specific Quantitative PCR Assays. Applied and Environmental Microbiology 71, 4117-4120.

Fierer, N., Strickland, M.S., Liptzin, D., Bradford, M.A., Cleveland, C.C., 2009. Global patterns in belowground communities. Ecology Letters 12, 1238-1249.

Garbeva, P., Postma, J., van Veen, J.A., van Elsas, J.D., 2006. Effect of above-ground plant species on soil microbial community structure and its impact on suppression of Rhizoctonia solani AG3. Environmental Microbiology 8, 233-246.

Hansen, T.H., de Bang, T.C., Laursen, K.H., Pedas, P., Husted, S., Schjoerring, J.K., 2013. Multielement plant tissue analysis using ICP spectrometry. Methods in molecular biology (Clifton, N.J.) 953, 121-141.

Hansen, T.H., Laursen, K.H., Persson, D.P., Pedas, P., Husted, S., Schjoerring, J.K., 2009. Micro-scaled highthroughput digestion of plant tissue samples for multi-elemental analysis. Plant Methods 5, 12.

Hattenschwiler, S., Gasser, P., 2005. Soil animals alter plant litter diversity effects on decomposition. Proc Natl Acad Sci U S A 102, 1519-1524.

Hattenschwiler, S., Tiunov, A.V., Scheu, S., 2005. Biodiversity and litter decomposition interrestrial ecosystems. Annual Review of Ecology Evolution and Systematics. Annual Reviews, Palo Alto, pp. 191-218.

Hobbie, S.E., 2008. Nitrogen effects on decomposition: a five-year experiment in eight temperate sites. Ecology 89, 2633-2644.

Holmberg, J., Bass, S., Timberlake, L., 1991. "Defending the Future", p. 13. Earthscan/IIED, London. 
Joergensen, R.G., Wichern, F., 2008. Quantitative assessment of the fungal contribution to microbial tissue in soil. Soil Biology and Biochemistry 40, 2977-2991.

Kallenbach, C.M., Frey, S.D., Grandy, A.S., 2016. Direct evidence for microbial-derived soil organic matter formation and its ecophysiological controls. Nat. Commun. 7.

Kallenbach, C.M., Rolston, D.E., Horwath, W.R., 2010. Cover cropping affects soil N2O and CO2 emissions differently depending on type of irrigation. Agric. Ecosyst. Environ. 137, 251-260.

Klamer, M., Bååth, E., 2004. Estimation of conversion factors for fungal biomass determination in compost using ergosterol and PLFA 18:2w6,9. Soil Biology and Biochemistry 36, 57-65.

Lal, R., 2004. Soil Carbon Sequestration Impacts on Global Climate Change and Food Security. Science 304, 16231627.

Lange, M., Eisenhauer, N., Sierra, C.A., Bessler, H., Engels, C., Griffiths, R.I., Mellado-Vazquez, P.G., Malik, A.A., Roy, J., Scheu, S., Steinbeiss, S., Thomson, B.C., Trumbore, S.E., Gleixner, G., 2015. Plant diversity increases soil microbial activity and soil carbon storage. Nat Commun 6, 6707.

Lehmann, J., Kleber, M., 2015. The contentious nature of soil organic matter. Nature 528, 60-68.

Liu, P., Huang, J., Han, X., Sun, O.J., Zhou, Z., 2006. Differential responses of litter decomposition to increased soil nutrients and water between two contrasting grassland plant species of Inner Mongolia, China. Applied Soil Ecology 34, 266-275.

Loreau, M., 2001. Microbial diversity, producer-decomposer interactions and ecosystem processes: a theoretical model. Proceedings. Biological sciences 268, 303-309.

Mallon, C.A., Elsas, J.D.v., Salles, J.F., 2015a. Microbial Invasions: The Process, Patterns, and Mechanisms. Trends in Microbiology 23, 719-729.

Mallon, C.A., Le Roux, X., van Doorn, G.S., Dini-Andreote, F., Poly, F., Salles, J.F., 2018. The impact of failure: unsuccessful bacterial invasions steer the soil microbial community away from the invader's niche. Isme Journal 12, 728-741.

Mallon, C.A., Poly, F., Le Roux, X., Marring, I., van Elsas, J.D., Salles, J.F., 2015b. Resource pulses can alleviate the biodiversity-invasion relationship in soil microbial communities. Ecology 96, 915-926.

Marschner, P., Hatam, Z., Cavagnaro, T.R., 2015. Soil respiration, microbial biomass and nutrient availability after the second amendment are influenced by legacy effects of prior residue addition. Soil Biology and Biochemistry 88, 169-177.

McCourty, M.A., Gyawali, A.J., Stewart, R.D., 2018. Of macropores and tillage: influence of biomass incorporation on cover crop decomposition and soil respiration. Soil Use and Management 34, 101-110.

Menzies, N.W., Donn, M.J., Kopittke, P.M., 2007. Evaluation of extractants for estimation of the phytoavailable trace metals in soils. Environmental Pollution 145, 121-130. 
Mooshammer, M., Wanek, W., Zechmeister-Boltenstern, S., Richter, A., 2014. Stoichiometric imbalances between terrestrial decomposer communities and their resources: mechanisms and implications of microbial adaptations to their resources. Frontiers in Microbiology 5, 10.

Nair, A., Ngouajio, M., 2012. Soil microbial biomass, functional microbial diversity, and nematode community structure as affected by cover crops and compost in an organic vegetable production system. Applied Soil Ecology 58, 45-55.

Nguyen, T.T., Cavagnaro, T.R., Thanh Ngo, H.T., Marschner, P., 2016. Soil respiration, microbial biomass and nutrient availability in soil amended with high and low $\mathrm{C} / \mathrm{N}$ residue - Influence of interval between residue additions. Soil Biology and Biochemistry 95, 189-197.

Nicolardot, B., Bouziri, L., Bastian, F., Ranjard, L., 2007. A microcosm experiment to evaluate the influence of location and quality of plant residues on residue decomposition and genetic structure of soil microbial communities. Soil Biology and Biochemistry 39, 1631-1644.

Norris, M.D., Avis, P.G., Reich, P.B., Hobbie, S.E., 2013. Positive feedbacks between decomposition and soil nitrogen availability along fertility gradients. Plant and Soil 367, 347-361.

Olson, K.R., Ebelhar, S.A., Lang, J.M., 2010. Cover Crop Effects on Crop Yields and Soil Organic Carbon Content. Soil Science 175, 89-98.

Partey, S.T., Preziosi, R.F., Robson, G.D., 2014. Improving maize residue use in soil fertility restoration by mixing with residues of low C-to-N ratio: effects on $\mathrm{C}$ and $\mathrm{N}$ mineralization and soil microbial biomass. J. Soil Sci. Plant Nutr. 14, 518-531.

Petersen, S.O., Mutegi, J.K., Hansen, E.M., Munkholm, L.J., 2011. Tillage effects on N2O emissions as influenced by a winter cover crop. Soil Biology and Biochemistry 43, 1509-1517.

Postma, J., Schilder, M.T., Bloem, J., van Leeumen-Haagsma, W.K., 2008. Soil suppressiveness and functional diversity of the soil microflora in organic farming systems. Soil Biology \& Biochemistry 40, 2394-2406.

Redin, M., Recous, S., Aita, C., Dietrich, G., Skolaude, A.C., Ludke, W.H., Schmatz, R., Giacomini, S.J., 2014. How the chemical composition and heterogeneity of crop residue mixtures decomposing at the soil surface affects C and N mineralization. Soil Biology and Biochemistry 78, 65-75.

Rutgers, M., Wouterse, M., Drost, S.M., Breure, A.M., Mulder, C., Stone, D., Creamer, R.E., Winding, A., Bloem, J., 2016. Monitoring soil bacteria with community-level physiological profiles using Biolog ${ }^{\mathrm{TM}}$ ECO-plates in the Netherlands and Europe. Applied Soil Ecology 97, 23-35.

Sakala, W.D., Cadisch, G., Giller, K.E., 2000. Interactions between residues of maize and pigeonpea and mineral $\mathrm{N}$ fertilizers during decomposition and N mineralization. Soil Biology and Biochemistry 32, 679-688.

Santelli, C.M., Orcutt, B.N., Banning, E., Bach, W., Moyer, C.L., Sogin, M.L., Staudigel, H., Edwards, K.J., 2008. Abundance and diversity of microbial life in ocean crust. Nature 453, 653. 
Shi, A., Marschner, P., 2014. Changes in microbial biomass C, extractable C and available N during the early stages of decomposition of residue mixtures. Soil Research 52, 366.

Tao, J., Liu, X., Liang, Y., Niu, J., Xiao, Y., Gu, Y., Ma, L., Meng, D., Zhang, Y., Huang, W., Peng, D., Yin, H., 2017. Maize growth responses to soil microbes and soil properties after fertilization with different green manures. Appl. Microbiol. Biotechnol. 101, 1289-1299.

Tsiafouli, M.A., Thebault, E., Sgardelis, S.P., de Ruiter, P.C., van der Putten, W.H., Birkhofer, K., Hemerik, L., de Vries, F.T., Bardgett, R.D., Brady, M.V., Bjornlund, L., Jorgensen, H.B., Christensen, S., D' Hertefeldt, T., Hotes, S., Hol, W.H.G., Frouz, J., Liiri, M., Mortimer, S.R., Setala, H., Tzanopoulos, J., Uteseny, K., Pizl, V., Stary, J., Wolters, V., Hedlund, K., 2015. Intensive agriculture reduces soil biodiversity across Europe. Global Change Biology 21, 973-985.

Van Elsas, J.D., Chiurazzi, M., Mallon, C.A., Elhottova, D., Kristufek, V., Salles, J.F., 2012. Microbial diversity determines the invasion of soil by a bacterial pathogen. Proceedings of the National Academy of Sciences of the United States of America 109, 1159-1164.

Van Elsas, J.D., Garbeva, P., Salles, J., 2002. Effects of agronomical measures on the microbial diversity of soils as related to the suppression of soil-borne plant pathogens. Biodegradation 13, 29-40.

Wagg, C., Bender, S.F., Widmer, F., van der Heijden, M.G.A., 2014. Soil biodiversity and soil community composition determine ecosystem multifunctionality. Proceedings of the National Academy of Sciences of the United States of America 111, 5266-5270.

Wang, K.H., McSorley, R., Kokalis-Burelle, N., 2006. Effects of Cover Cropping, Solarization, and Soil Fumigation on Nematode Communities. Plant and Soil 286, 229-243.

Wardle, D.A., Bardgett, R.D., Klironomos, J.N., Setala, H., van der Putten, W.H., Wall, D.H., 2004. Ecological linkages between aboveground and belowground biota. Science 304, 1629-1633.

Wardle, D.A., Yeates, G.W., Barker, G.M., Bonner, K.I., 2006. The influence of plant litter diversity on decomposer abundance and diversity. Soil Biology and Biochemistry 38, 1052-1062.

Xu, X., Thornton, P.E., Post, W.M., 2013. A global analysis of soil microbial biomass carbon, nitrogen and phosphorus in terrestrial ecosystems. Global Ecology and Biogeography 22, 737-749.

Zechmeister-Boltenstern, S., Keiblinger, K.M., Mooshammer, M., Penuelas, J., Richter, A., Sardans, J., Wanek, W., 2015. The application of ecological stoichiometry to plant-microbial-soil organic matter transformations. Ecological Monographs 85.

Zhong, Y., Yan, W., Wang, R., Shangguan, Z., 2017. Differential responses of litter decomposition to nutrient addition and soil water availability with long-term vegetation recovery. Biology and Fertility of Soils 53, 939949.

Zhou, X.Q., Wu, H.W., Koetz, E., Xu, Z.H., Chen, C.R., 2012. Soil labile carbon and nitrogen pools and microbial metabolic diversity under winter crops in an arid environment. Applied Soil Ecology 53, 49-55. 
Figure 1: Fungal biomass ( $\mathrm{mg}$ ergosterol ${ }^{*} \mathrm{~kg} \mathrm{soil}^{-1}$ ) over time (mean $\left.\pm S E ; n=4\right)$. A: control, monocultures $\mathrm{V}, \mathrm{R}, \mathrm{A}$ and $\mathrm{A}+\mathrm{N}$; $\mathrm{B}$ : control, mixtures VRA and 15sp. expVRA is the average of the three monocultures ( $\mathrm{V}, \mathrm{R}$ and $\mathrm{A})$. The results of the statistical test are shown in Table S1.

648

Figure 2: Bacterial biomass (based on copy numbers of the $16 \mathrm{~S}$ rRNA gene with qPCR) over time (mean $\pm S E ; n=4$ ). A: control, monocultures $V, R, A$ and $A+N$; B: control, mixtures VRA and 15sp. expVRA is the average of the three monocultures $(V, R$ and $A)$. The results of the statistical test are shown in Table S2.

653

Figure 3: Microbial functional diversity: number of wells that showed a positive response in Biolog ECO plates after incubation of 7 days (mean $\pm S E ; n=4$ ). As the treatments are not significantly different over time $(p=0.59)$, the average of both time points (T12 and T50) is shown here (complete graph is Figure S1). The different letters indicate significant differences between treatments. The results of the statistical test are shown in Table S6.

659

Figure 4: RDA (Redundancy Analyses) ordination plot based on positive/negative (1/0) results of the data from the Biolog ECO 96 well plates after 7 days of incubation. The letters indicate the different substrates and are listed in Table S9. Time was significantly related to the results of the Biolog ECO plates $(P=0.004)$, microbial biomass was not significantly correlated with the results. The results of the RDA are shown in Table S7 and Table S8. Correlations between the environmental variables are shown in Table S10.

666

Figure 5: Greenhouse gas fluxes over time (days) (mean $\pm \mathrm{SE} ; \mathrm{n}=4$ ). A: $\mathrm{mmol} \mathrm{CO}_{2}$ per hour per $\mathrm{m}^{2}$; B: $\mu$ mol $\mathrm{N}_{2} \mathrm{O}$ per hour per $\mathrm{m}^{2} ;$ C: close-up of $\mathrm{N}_{2} \mathrm{O}$ graph. The results of the statistical test are shown in Table S11 and Table S12.

670

Figure 6: Cumulative greenhouse gas fluxes of both $\mathrm{CO}_{2}$ and $\mathrm{N}_{2} \mathrm{O}$ calculated as $\mathrm{CO}_{2}$ equivalent values (mean $\pm S E ; n=4$ ). The letters indicate significant differences between the treatments. The 
673 results of the statistical test are shown in Table S13. The separate cumulative greenhouse gas fluxes

674 of both $\mathrm{CO}_{2}$ and $\mathrm{N}_{2} \mathrm{O}$ are shown in Figure $\mathrm{S} 4$.

675

676

Figure 7: $\mathrm{N}$ content (mg per kg of dry soil) in the soil at the different time points (in days) (mean $\pm \mathrm{SE}$;

677 $\mathrm{n}=4$ ). $\mathrm{A}: \mathrm{NO}_{3}$; Letters indicate significant differences between the treatments. The treatments show

678 similar increase over time. $\mathbf{B}: \mathrm{NH}_{4}$. There are no significant differences between the treatments in $\mathrm{B}$

679 (only $\mathrm{A}+\mathrm{N}$ was significantly different at T12), the asterisk indicate the significant difference between

680 T12 and T50 of A+N. The results of the statistical test are shown in Table S14 and Table S15.

681

682

Figure 8: Percentage of nutrients that is released from the added plant material in the soil at the 683 different time points (in days) (mean $\pm S E ; n=4)$. A: K; B: P; C: S.

684

685

686

Tables

687

688

Table 1: Nutrient content of the added plant material

\begin{tabular}{lcccccc}
\hline & $\mathbf{N}$ & $\mathbf{C}$ & $\mathbf{C : N}$ & $\mathbf{K}$ & $\mathbf{P}$ & $\mathbf{S}$ \\
\hline & $\left(\mathrm{g}^{*} \mathrm{~kg}^{-1}\right)$ & $\left(\mathrm{g}^{\star} \mathrm{kg}^{-1}\right)$ & & $\left(\mathrm{g}^{*} \mathrm{~kg}^{-1}\right)$ & $\left(\mathrm{g}^{*} \mathrm{~kg}^{-1}\right)$ & $\left(\mathrm{g}^{*} \mathrm{~kg}^{-1}\right)$ \\
V. sativa (V) & 39.7 & 327.6 & 8.26 & 21.23 & 5.87 & 3.21 \\
R. sativus (R) & 24.5 & 382.7 & 15.64 & 12.17 & 5.49 & 3.14 \\
A. strigosa (A) & 12.0 & 373.0 & 31.16 & 2.79 & 1.91 & 1.16 \\
3 species (VRA) & 25.4 & 361.1 & 14.23 & 12.06 & 4.42 & 2.51 \\
15 species (15sp) & 18.1 & 364.6 & 20.16 & 9.56 & 3.31 & 2.32 \\
\hline
\end{tabular}

689

690 

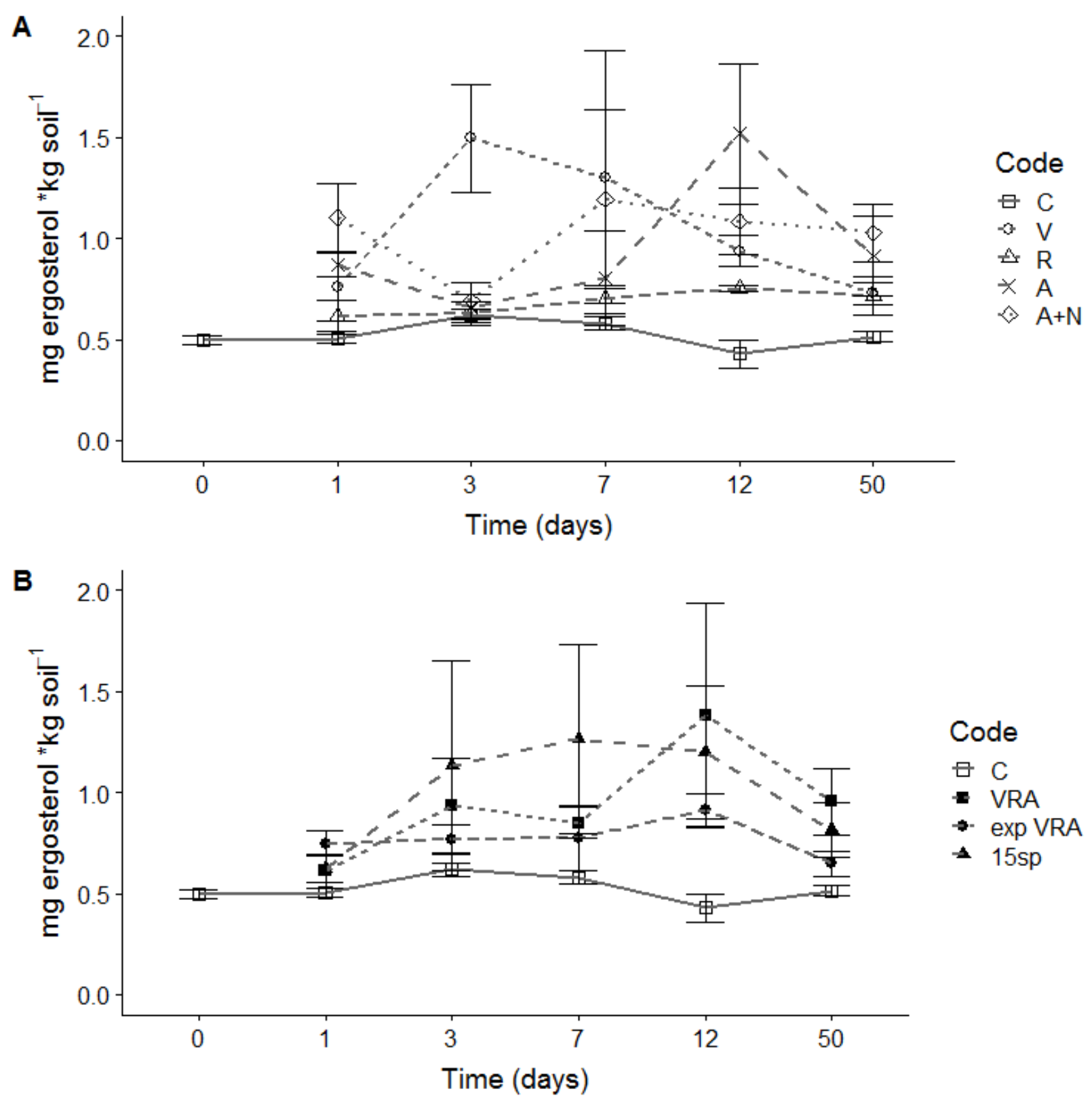

691

692 Figure 1

693 

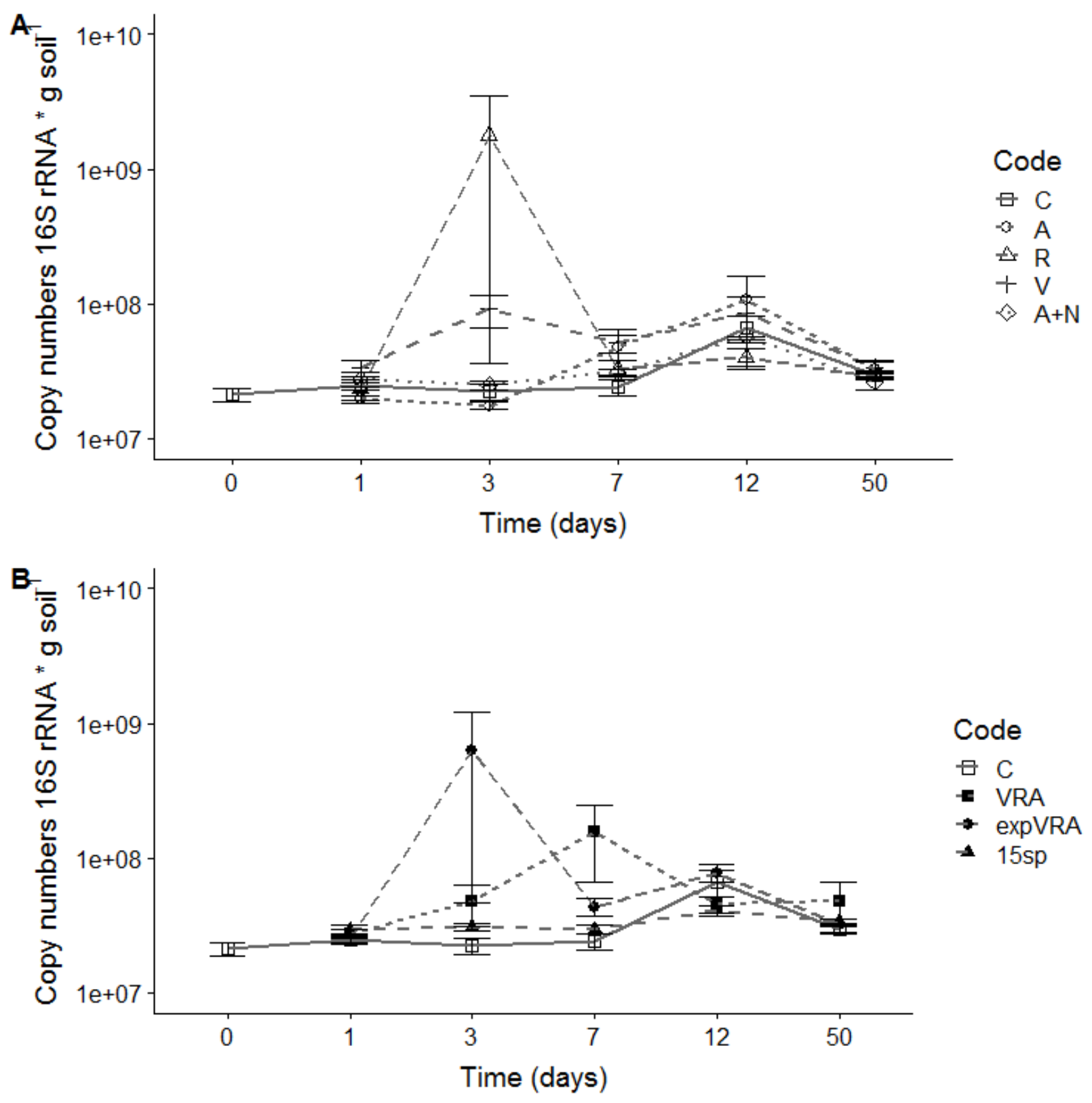

694

695 Figure 2

696 
697

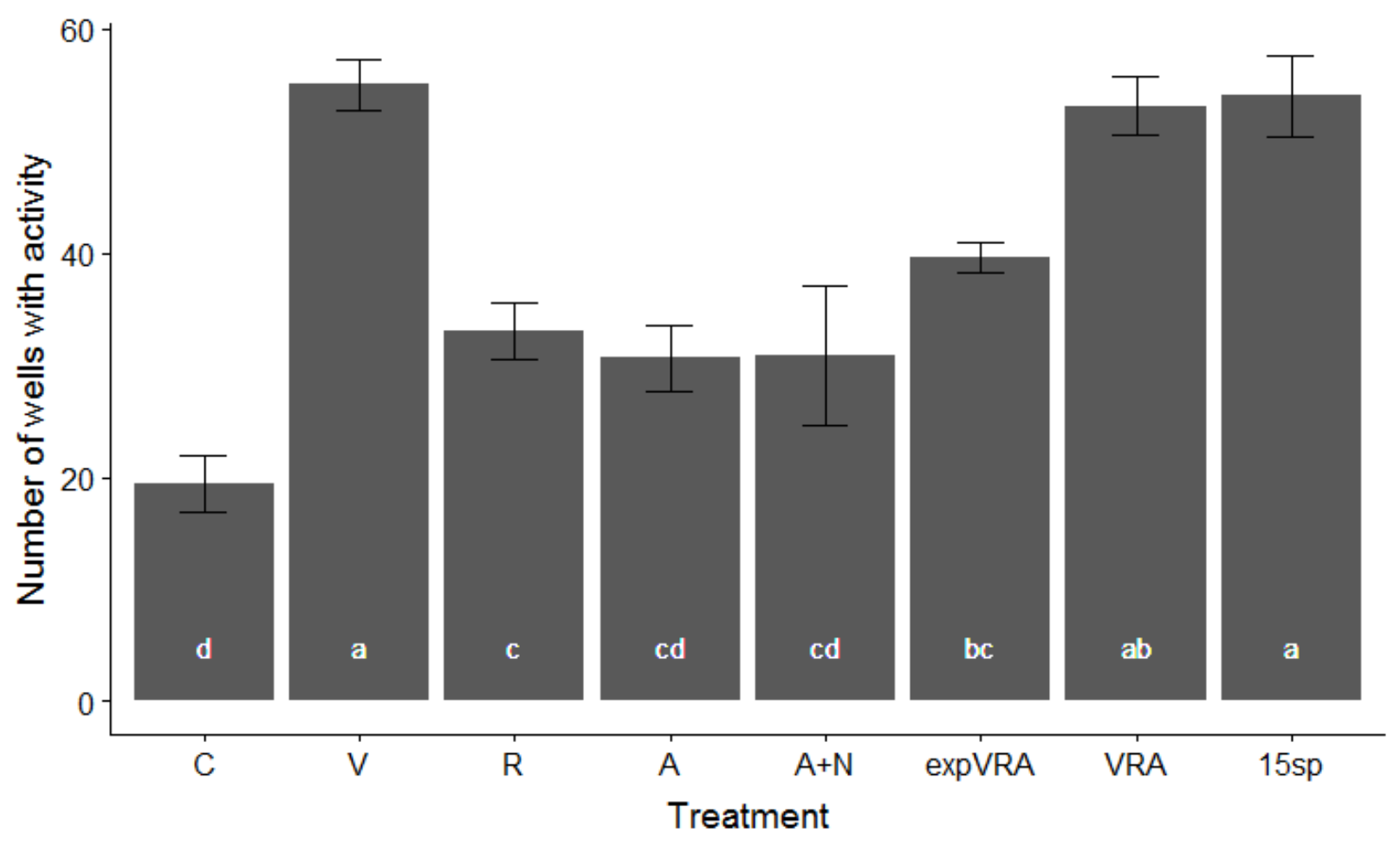

698

$699 \quad$ Figure 3

700 


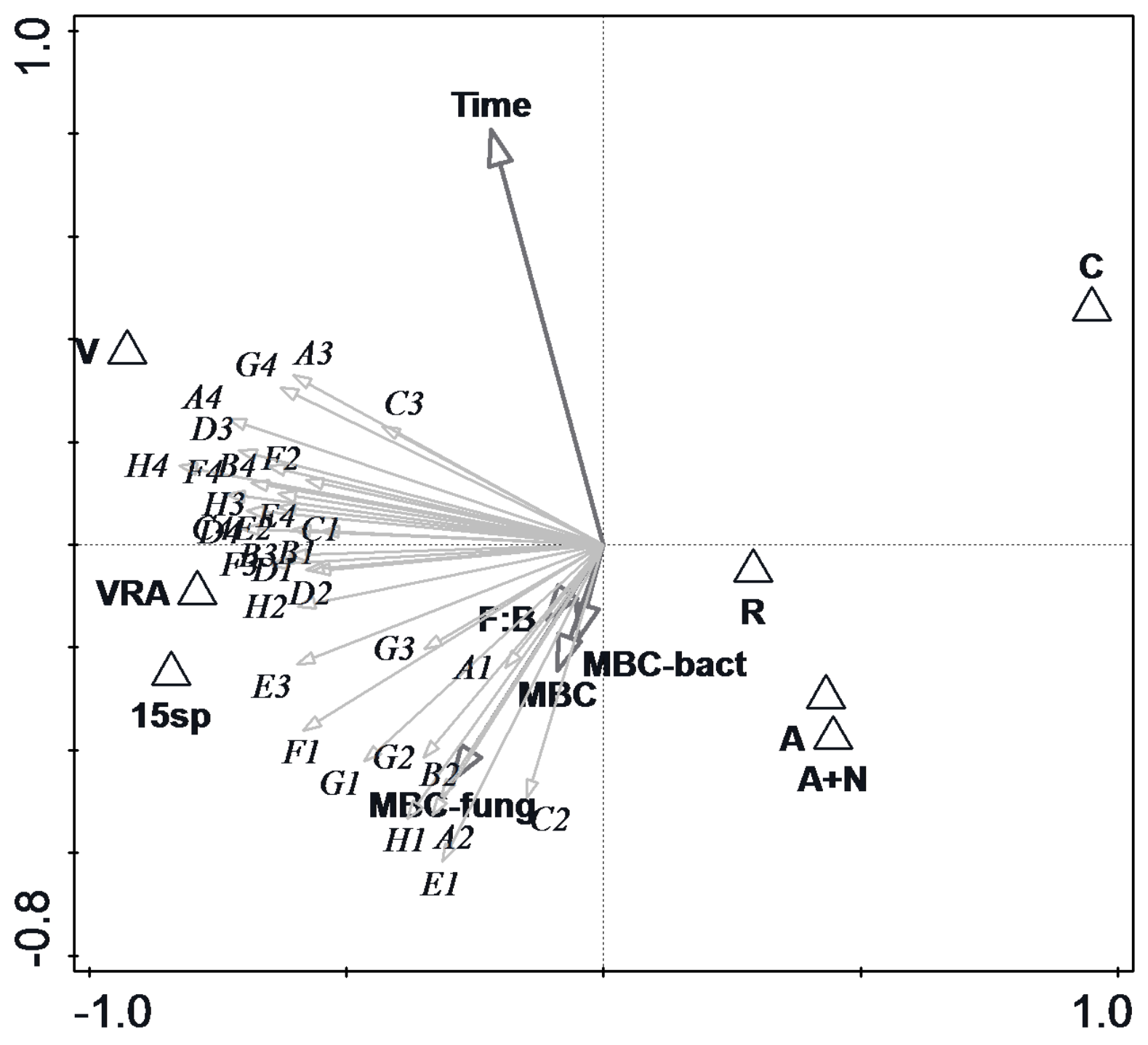

702

703 Figure 4

704 


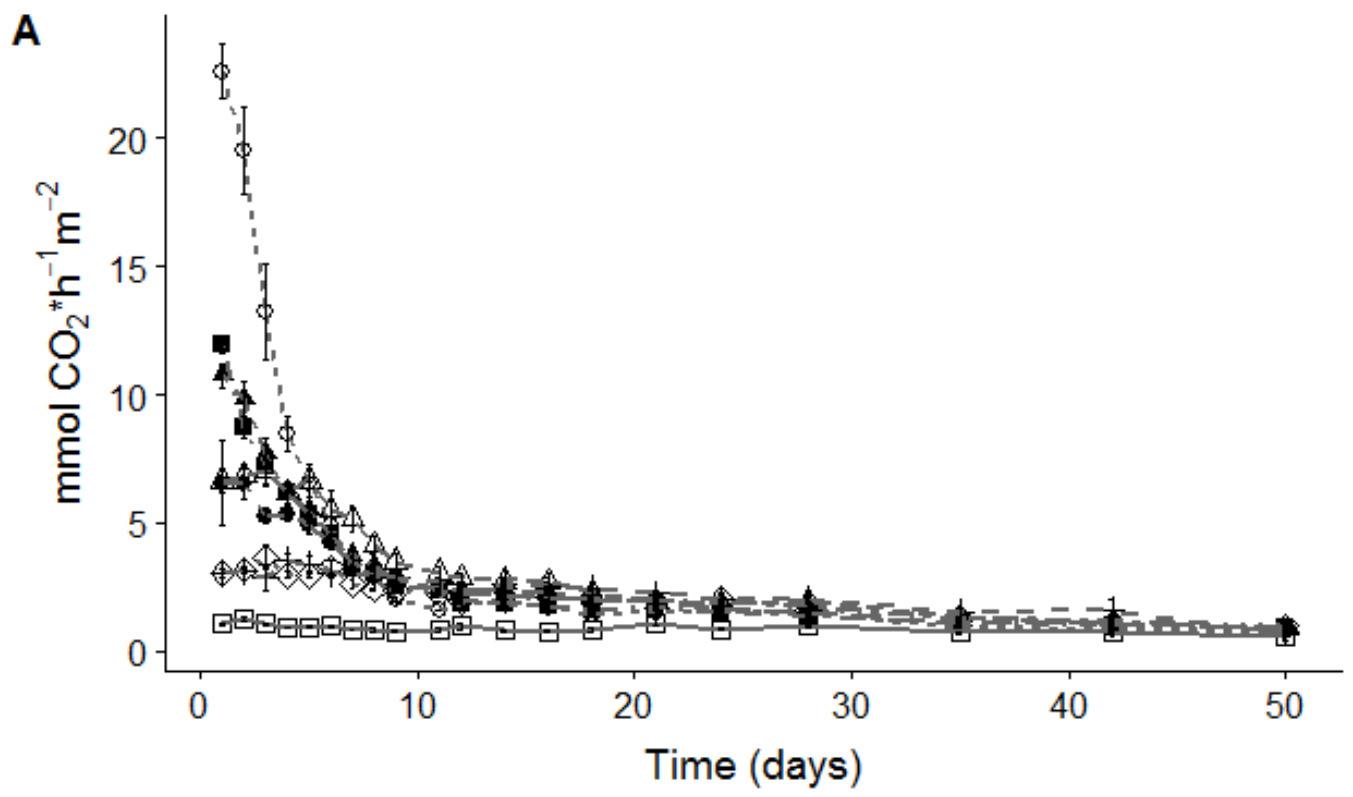

Code

$\square \mathrm{C}$

$\rightarrow \mathrm{V}$

$\Delta \mathrm{R}$

$+\mathrm{A}$

$\Leftrightarrow \mathrm{A}+\mathrm{N}$

- VRA

- 15sp

- $\operatorname{expVRA}$

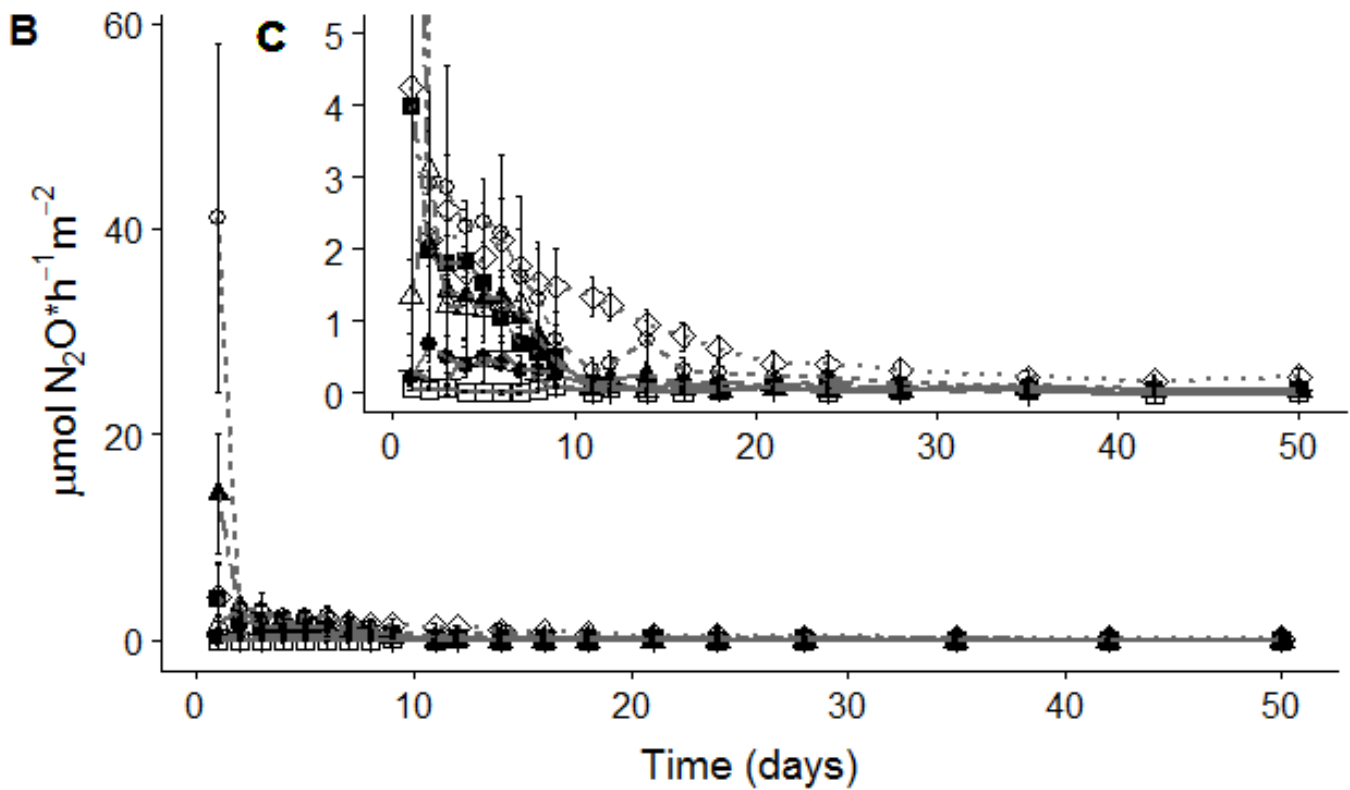

Code

$\because \mathrm{C}$

$-\infty \mathrm{V}$

$\therefore \mathrm{R}$

$+\mathrm{A}$

$\Leftrightarrow A+N$

- VRA

- 15sp

^ $\_$expVRA

Figure 5

707 


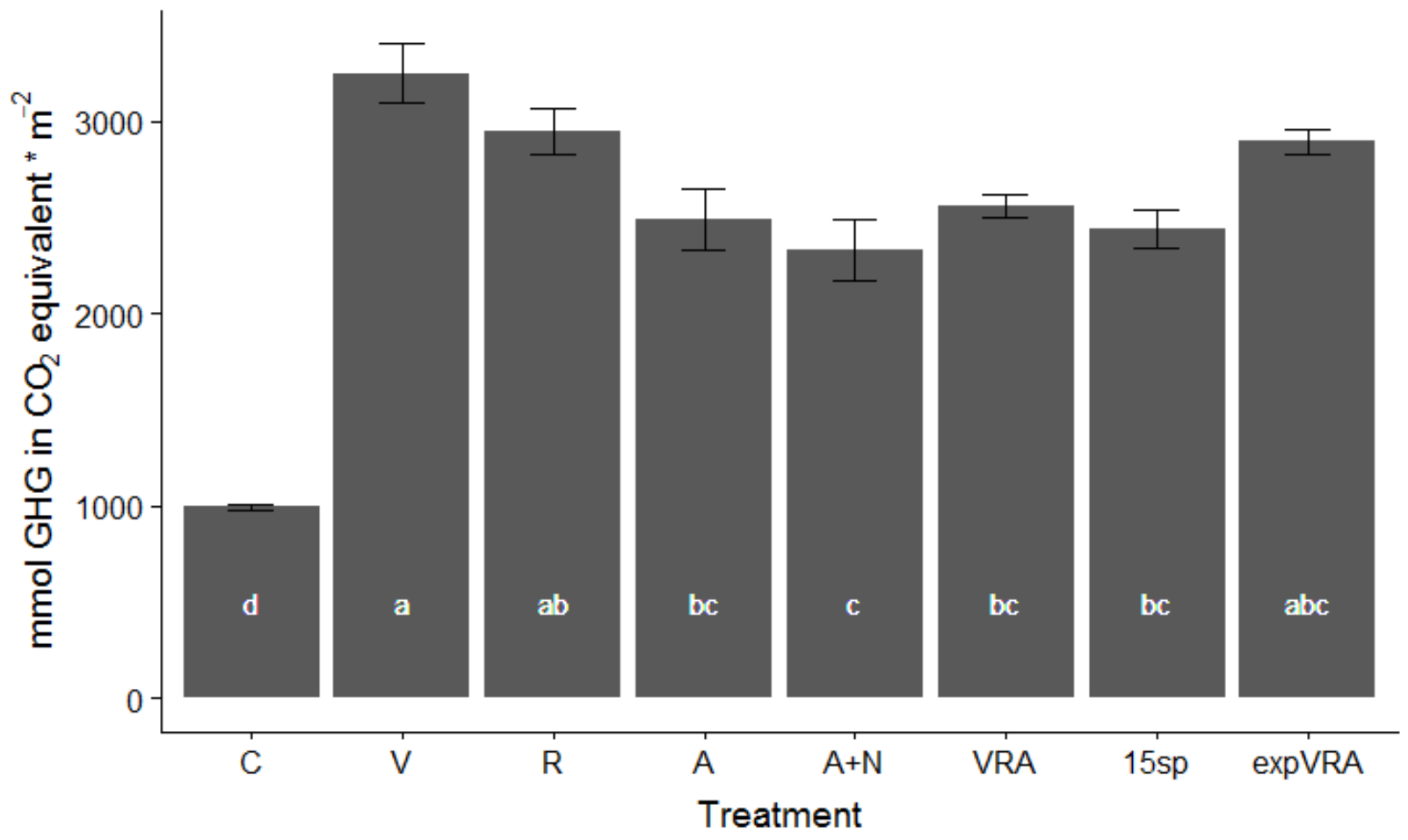

708

$709 \quad$ Figure 6

710 

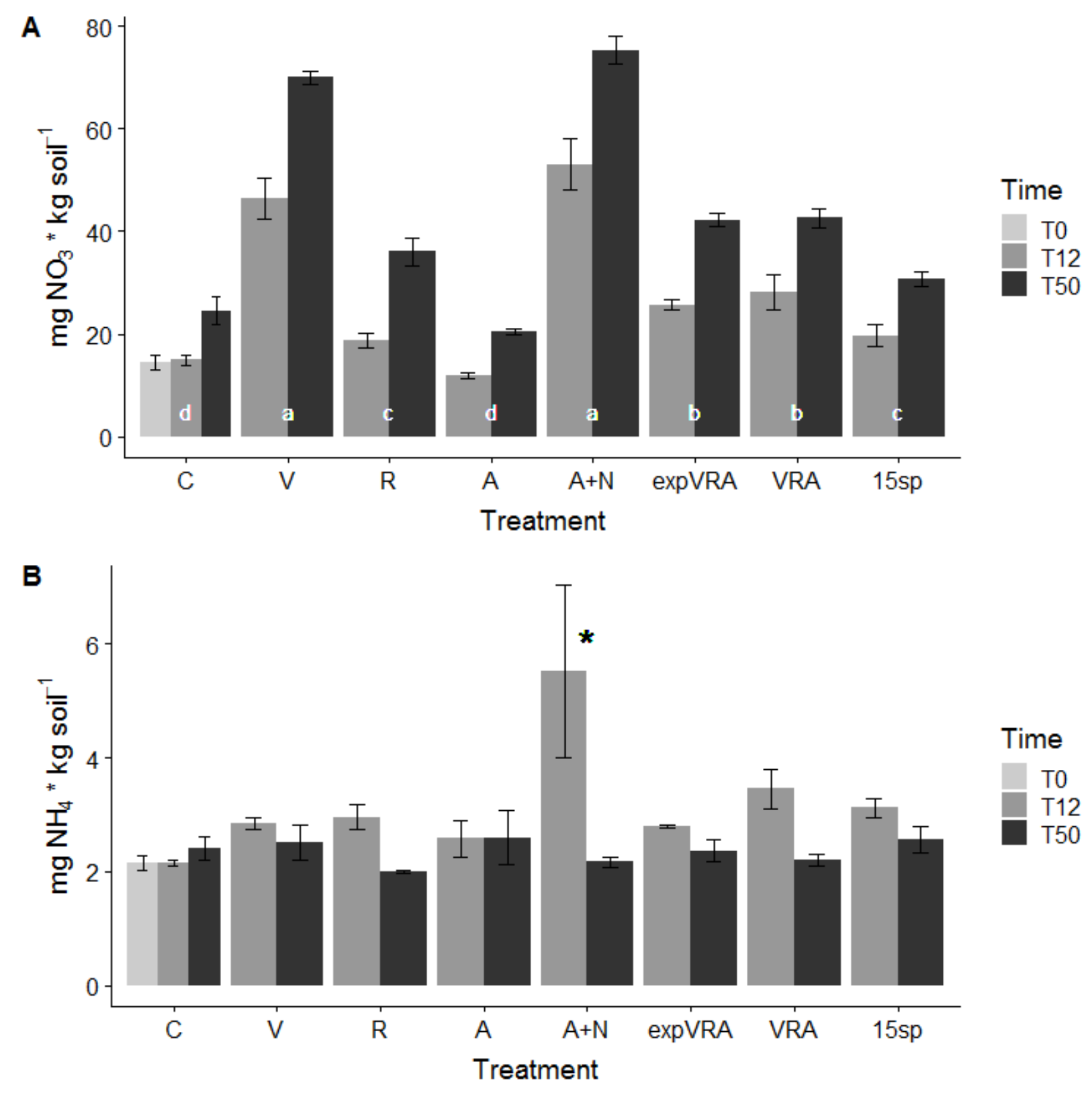

Figure 7 

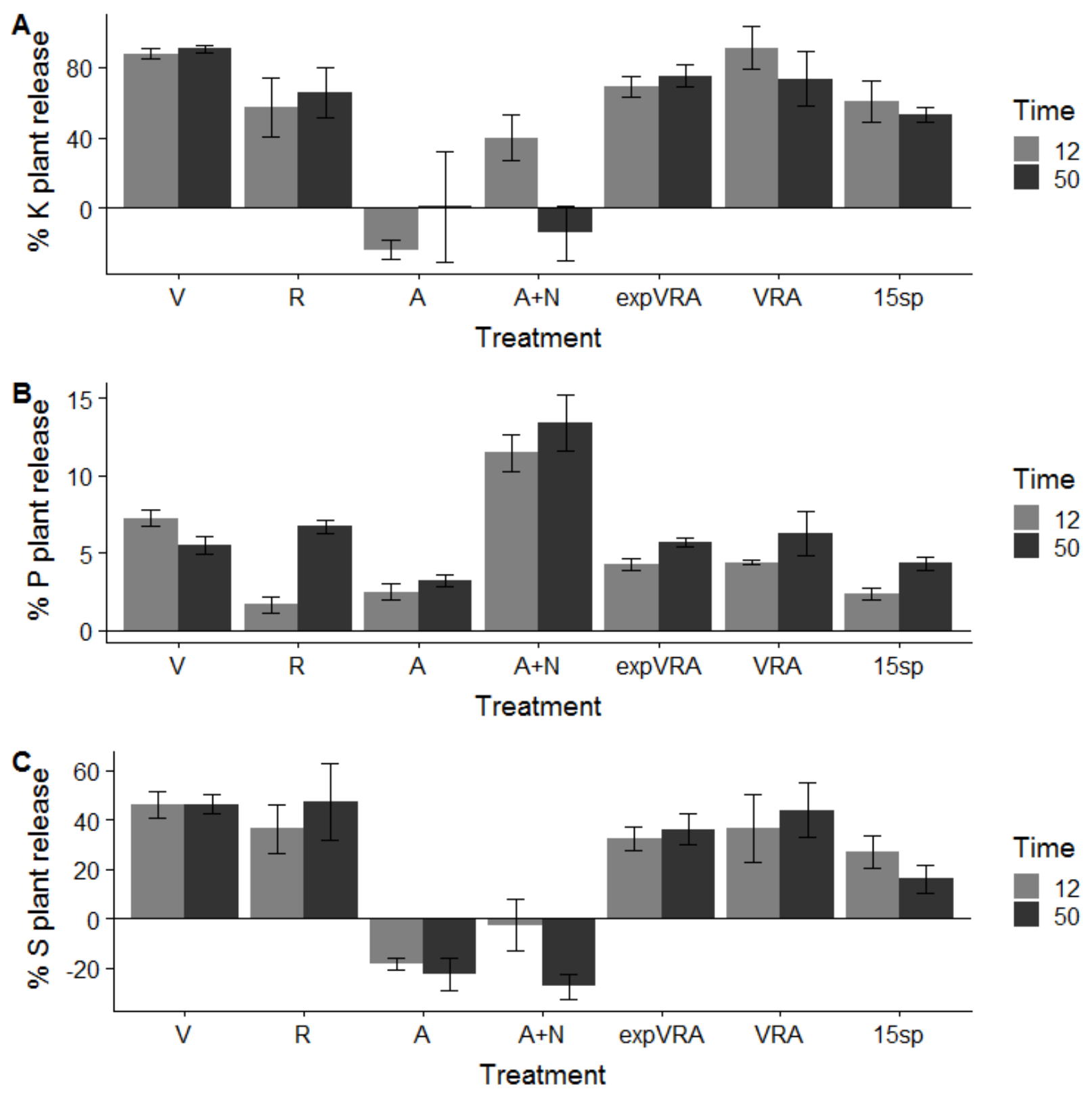

Figure 8

716 
719

Table S1: Result statistical test of ergosterol (with Anova). Df is degrees of freedom, Sum Sq is sum of squares, Mean $\mathrm{Sq}$ is mean sum of squares.

\begin{tabular}{llllll}
\hline & Df & Sum Sq & Mean Sq & F value & P-value \\
\hline Treatment & 7 & 2.1826 & 0.311802 & 8.0318 & $\mathbf{5 . 3 5 3 e - 0 8}$ \\
Time & 5 & 0.1946 & 0.038924 & 1.0026 & 0.4192 \\
Time ${ }^{\star}$ Treatment & 7 & 1.4066 & 0.050236 & 1.2940 & 0.1710 \\
Residuals & 146 & 4.6973 & 0.038821 & & \\
\hline
\end{tabular}

722

723

Table S2: Result statistical test of the copy numbers of the $16 \mathrm{~S}$ rRNA gene (with Anova). Df is

724 degrees of freedom, Sum Sq is sum of squares, Mean Sq is mean sum of squares.

\begin{tabular}{llllll}
\hline & Df & Sum Sq & Mean Sq & F value & P-value \\
\hline Treatment & 7 & $1.3584 \mathrm{e}-13$ & $1.9405 \mathrm{e}-14$ & 7.0563 & $\mathbf{4 . 4 7 3 e - 0 7}$ \\
Time & 5 & $1.8413 \mathrm{e}-13$ & $3.6826 \mathrm{e}-14$ & 13.3909 & $\mathbf{2 . 0 1 7 e - 1 0}$ \\
Time`Treatment & 28 & $1.6517 \mathrm{e}-13$ & $5.8990 \mathrm{e}-15$ & 2.1450 & $\mathbf{0 . 0 0 2 3 5 6}$ \\
Residuals & 123 & $3.3826 \mathrm{e}-13$ & $2.7500 \mathrm{e}-15$ & & \\
& & & & & \\
\hline
\end{tabular}

725

726 Table S3: Calculated microbial biomass $\mathrm{C}(\mathrm{MBC})$ in $\mathrm{mg} \mathrm{C}$ per kg soil and fungi:bacteria ratio ( $\mathrm{F}: \mathrm{B})$

727 based on 16S and ergosterol content in the soil over time. The results of the statistical test are shown 728 in Table S4 and S5.

\begin{tabular}{rlllllllll}
\hline Time & & C & V & R & A & A+N & VRA & exp VRA & 15sp \\
\hline 0 & MBC & $0.45 \pm 0.07$ & & & & & & & \\
& $F: B$ & $0.34 \pm 0.09$ & & & & & & & \\
1 & MBC & $0.51 \pm 0.04$ & $0.49 \pm 0.07$ & $0.51 \pm 0.11$ & $0.73 \pm 0.13$ & $0.69 \pm 0.15$ & $0.60 \pm 0.04$ & $0.58 \pm 0.06$ & $0.61 \pm 0.09$ \\
& F:B & $0.29 \pm 0.07$ & $0.56 \pm 0.29$ & $0.43 \pm 0.28$ & $0.39 \pm 0.13$ & $0.58 \pm 0.19$ & $0.30 \pm 0.09$ & $0.42 \pm 0.09$ & $0.30 \pm 0.06$ \\
3 & MBC & $0.47 \pm 0.09$ & $0.56 \pm 0.11$ & $28.8 \pm 56.3$ & $1.59 \pm 0.83$ & $0.53 \pm 0.08$ & $0.94 \pm 0.59$ & $10.3 \pm 18.8$ & $0.70 \pm 0.22$ \\
& F:B & $0.34 \pm 0.09$ & $1.00 \pm 0.34$ & $0.16 \pm 0.13$ & $0.10 \pm 0.05$ & $0.32 \pm 0.06$ & $0.26 \pm 0.13$ & $0.18 \pm 0.13$ & $0.41 \pm 0.35$ \\
7 & MBC & $0.50 \pm 0.11$ & $1.00 \pm 0.74$ & $0.66 \pm 0.19$ & $0.97 \pm 0.28$ & $0.72 \pm 0.13$ & $2.67 \pm 2.89$ & $0.88 \pm 0.28$ & $0.71 \pm 0.16$
\end{tabular}




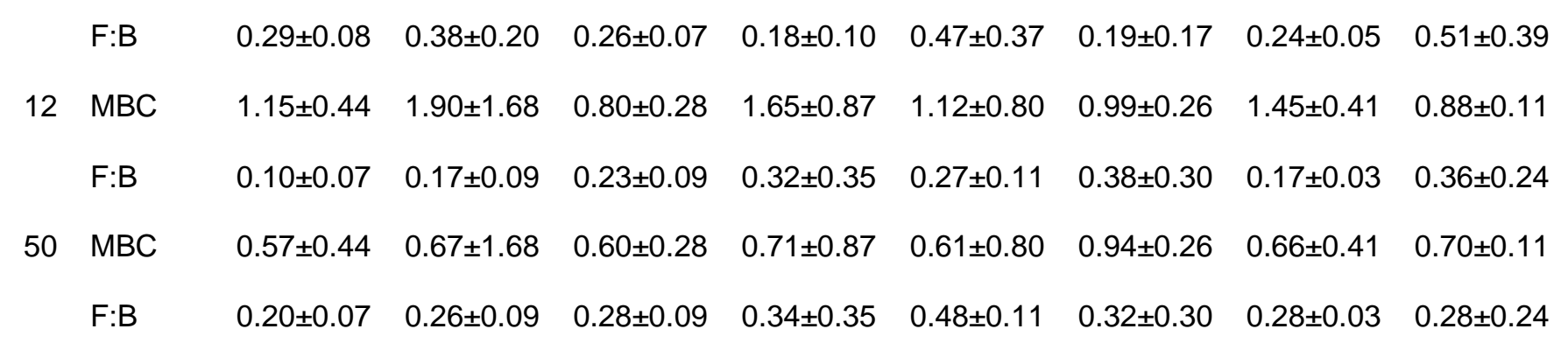

729

730

731 Table S4: Result statistical test of the soil microbial biomass C (MBC) (with Anova). Df is degrees of 732 freedom, Sum Sq is sum of squares, Mean Sq is mean sum of squares.

\begin{tabular}{llllll}
\hline & Df & Sum Sq & Mean Sq & F value & P-value \\
\hline Treatment & 7 & 1.9754 & 0.28220 & 5.7023 & $1.031 \mathrm{e}-05$ \\
Time & 5 & 2.4063 & 0.48127 & 9.7249 & $7.923 \mathrm{e}-08$ \\
Time & & 1.9986 & 0.07138 & 1.4423 & 0.09049 \\
Residuals & 121 & 5.9881 & 0.04949 & & \\
\hline
\end{tabular}

733

734 Table S5: Result statistical test of the fungi:bacteria ratio (with Anova). Df is degrees of freedom, Sum

735 Sq is sum of squares, Mean Sq is mean sum of squares.

\begin{tabular}{llllll}
\hline & Df & Sum Sq & Mean Sq & F value & P-value \\
\hline Treatment & 7 & 1.0004 & 0.142911 & 4.0883 & 0.0004628 \\
Time & 5 & 0.4695 & 0.093897 & 2.6861 & 0.0244125 \\
Time & & 2.4501 & 0.087502 & 2.5032 & 0.0003126 \\
Residuals & 121 & 4.2297 & 0.034956 & & \\
\hline
\end{tabular}

736

737 Table S6: Result statistical test of the biolog ECO plates (with Anova). Df is degrees of freedom, Sum

$738 \mathrm{Sq}$ is sum of squares, Mean Sq is mean sum of squares.

\begin{tabular}{llllll}
\hline & Df & Sum Sq & Mean Sq & F value & P-value \\
\hline Treatment & 7 & 11389.5 & 1627.08 & 20.9820 & $\mathbf{5 . 5 2 5 e - 1 3}$ \\
Time & 2 & 83.8 & 41.92 & 0.5406 & 0.58571 \\
Time & & 1321.4 & 188.77 & 2.4343 & $\mathbf{0 . 0 3 1 2 6}$
\end{tabular}


740 Table S7: Summary table RDA biolog ECO plates.

\begin{tabular}{lllll}
\hline Statistic & Axis 1 & Axis 2 & Axis 3 & Axis 4 \\
\hline Eigenvalues & 0.3413 & 0.0727 & 0.0145 & 0.0099 \\
Explained variation (cumulative) & 34.13 & 41.4 & 42.85 & 43.84 \\
Pseudo-canonical correlation & 0.8497 & 0.8269 & 0.7102 & 0.6944 \\
Explained fitted variation & 75.17 & 91.18 & 94.37 & 96.55 \\
(cumulative) & & & & \\
\hline
\end{tabular}

741

742 Table S8: Analysis table of the RDA biolog ECO plates to identify significant contributors to the RDA

743 plot. P-adjusted is $\mathrm{P}$ value corrected with Bonferroni correction.

\begin{tabular}{lrrrr}
\hline Name & Explains \% & pseudo-F & P-value & P-adjusted \\
\hline Treatment: C & 15.5 & 10.5 & $\mathbf{0 . 0 0 2}$ & $\mathbf{0 . 0 2 4}$ \\
Treatment: V & 9.6 & 6 & $\mathbf{0 . 0 0 2}$ & $\mathbf{0 . 0 2 4}$ \\
Treatment: 15sp & 8.2 & 5.1 & $\mathbf{0 . 0 0 4}$ & $\mathbf{0 . 0 4 8}$ \\
Treatment: VRA & 6.9 & 4.2 & $\mathbf{0 . 0 1 4}$ & 0.168 \\
Time & 6.6 & 4.1 & $\mathbf{0 . 0 0 6}$ & 0.072 \\
MBC-fungus & 5.2 & 3.1 & $\mathbf{0 . 0 2 2}$ & 0.264 \\
Treatment: A+N & 2.7 & 1.6 & 0.148 & 1 \\
Treatment: A & 2.5 & 1.5 & 0.162 & 1 \\
MBC & 1.5 & 0.8 & 0.436 & 1 \\
Treatment: R & 1.4 & 0.8 & 0.476 & 1 \\
F:B & 1.2 & 0.7 & 0.64 & 1 \\
MBC-bacteria & 1.1 & 0.6 & 0.702 & 1 \\
\hline
\end{tabular}


745 Table S9: Substrates in Biolog ECO plates as carbon sources for the microbial community.

\begin{tabular}{|c|c|c|}
\hline Code & Substrate & Substrate group \\
\hline A1 & Water & Blank \\
\hline A2 & $\beta$-Methyl-D-glucoside & Carbohydrate \\
\hline A3 & D-Galactonic acid $\mathrm{y}$-lactone & Carbohydrate \\
\hline A4 & L-Arginine & Amino acid \\
\hline B1 & Methylpyruvate (Pyruvic Acid Methyl Ester) & Ester \\
\hline B2 & D-Xylose & Carbohydrate \\
\hline B3 & D-Galacturonic acid & Carboxylic acid/sugar acid \\
\hline B4 & L-Asparagine & Amino acid \\
\hline C1 & Tween 40 & Polymer \\
\hline C2 & i-Erythritol & Carbohydrate \\
\hline C3 & 2-Hydroxybenzoate & phenolic compound \\
\hline C4 & L-Phenylalanine & Amino acid \\
\hline D1 & Tween 80 & Polymer \\
\hline D2 & D-Mannitol & Carbohydrate \\
\hline D3 & 4-Hydroxybenzoate & phenolic compound \\
\hline D4 & L-Serine & Amino acid \\
\hline E1 & a-Cyclodextrin & Polymer \\
\hline E2 & N-Acetyl-D-glucosamine & Carbohydrate \\
\hline E3 & Y-Hydroxy-butyric acid & Carboxylic acid \\
\hline E4 & L-Threonine & Amino acid \\
\hline F1 & Glycogen & Polymer \\
\hline F2 & D-Glucosaminic acid & Carboxylic acid \\
\hline F3 & Itaconic acid & Carboxylic acid \\
\hline F4 & Glycyl-L-glutamic acid & Amino acid \\
\hline G1 & D-Cellobiose & Carbohydrate \\
\hline G2 & Glucose-1-phosphate & Phosphorylated compound \\
\hline G3 & $\alpha-K e t o b u t y r i c ~ a c i d$ & Carboxylic acid \\
\hline G4 & Phenyl-ethylamine & Amide/amine \\
\hline
\end{tabular}



H1 a-D-Lactose
Carbohydrate
H2 D,L-a-Glycerol phosphate
Phosphorylated compound
H3 D-Malic acid
Carboxylic acid
H4 Putrescine
Amide/amine

Table S10: Correlation table between the environmental variables used for the RDA analysis. Lower

748 left part of the table are the correlation coefficients. Upper right panel are the P-values of the

749 corresponding correlation.

\begin{tabular}{lccccc}
\hline & \multicolumn{1}{l}{ Time } & $\begin{array}{l}\text { Fungal } \\
\text { biomass }\end{array}$ & $\begin{array}{l}\text { Bacterial } \\
\text { biomass }\end{array}$ & MBC & F:B ratio \\
\hline Time & 0.30 & 0.031 & 0.024 & 0.37 \\
$\begin{array}{l}\text { Fungal } \\
\text { biomass }\end{array}$ & -0.14 & & 0.49 & 0.082 & $<0.001$ \\
Bacterial & -0.28 & 0.09 & & & \\
biomass & -0.29 & 0.23 & 0.99 & $<0.001$ & $<0.001$ \\
MBC & 0.12 & 0.72 & -0.43 & -0.32 & 0.014 \\
F:B ratio & & & & & \\
\hline
\end{tabular}

750

751 Table S11: Result statistical test of the $\mathrm{CO}_{2}$ emisisons over time (with Kruskal-Wallis rank sum test).

752 Df is degrees of freedom.

\begin{tabular}{llll}
\hline & Chi-squared & Df & P-value \\
\hline Treatment & 185.76 & 7 & $<2.2 \mathrm{e}-16$ \\
Time & 356.99 & 19 & $<2.2 \mathrm{e}-16$ \\
\hline
\end{tabular}

753

754 Table S12: Result statistical test of the $\mathrm{N}_{2} \mathrm{O}$ emisisons over time (with Kruskal-Wallis rank sum test).

755 Df is degrees of freedom.

\begin{tabular}{llll}
\hline & Chi-squared & Df & P-value \\
\hline Treatment & 186.29 & 7 & $<2.2 \mathrm{e}-16$ \\
Time & 246.08 & 19 & $<2.2 \mathrm{e}-16$ \\
\hline
\end{tabular}


Table S13: Result statistical test of the cumulative GHG fluxes (with Anova). Df is degrees of freedom, Sum Sq is sum of squares, Mean Sq is mean sum of squares.

\begin{tabular}{llllll}
\hline & Df & Sum Sq & Mean Sq & F value & P-value \\
\hline Treatment & 7 & 12855295 & 1836471 & 35.216 & $\mathbf{4 . 0 4 1 e - 1 1}$ \\
Residuals & 24 & 1251563 & 52148 & & \\
\hline
\end{tabular}

759

Table S14: Result statistical test of the $\mathrm{NO}_{3}$ content in the soil (with Anova). Df is degrees of freedom,

761 Sum Sq is sum of squares, Mean Sq is mean sum of squares.

\begin{tabular}{llllll}
\hline & Df & Sum Sq & Mean Sq & F value & P-value \\
\hline Treatment & 7 & 15.3757 & 2.19653 & 102.2832 & $<2 \mathrm{e}-\mathbf{1 6}$ \\
Time & 2 & 3.9127 & 1.95637 & 91.0997 & $<2 \mathrm{e}-\mathbf{1 6}$ \\
Time & & & & 0.6532 \\
Residuals & 51 & 1.0952 & 0.02148 & & \\
\hline
\end{tabular}

762

763

Table S15: Result statistical test of the $\mathrm{NH}_{4}$ content in the soil (with Anova). Df is degrees of freedom,

Sum Sq is sum of squares, Mean Sq is mean sum of squares.

\begin{tabular}{llllll}
\hline & Df & Sum Sq & Mean Sq & F value & P-value \\
\hline Treatment & 7 & 0.045870 & 0.006553 & 2.2178 & $\mathbf{0 . 0 4 7 8 4}$ \\
Time & 2 & 0.085545 & 0.042772 & 14.4764 & $\mathbf{1 . 0 4 9 e - 0 5}$ \\
Time*Treatment & 7 & 0.057577 & 0.008225 & 2.7838 & $\mathbf{0 . 0 1 5 6 8}$ \\
Residuals & 51 & 0.150686 & 0.002955 & & \\
\hline
\end{tabular}

765

Table S16: Result statistical test of the $\mathrm{K}$ content in the soil (with Anova). Df is degrees of freedom,

Sum Sq is sum of squares, Mean Sq is mean sum of squares.

\begin{tabular}{llllll}
\hline & Df & Sum Sq & Mean Sq & F value & P-value \\
\hline Treatment & 7 & $3.0723 \mathrm{e}-05$ & $4.389 \mathrm{e}-06$ & 74.3937 & $<\mathbf{2 . 2 e - 1 6}$ \\
Time & 2 & $1.3819 \mathrm{e}-06$ & $6.910 \mathrm{e}-07$ & 11.7119 & $\mathbf{6 . 5 2 2 e - 0 5}$ \\
Time`Treatment & 7 & $3.0570 \mathrm{e}-07$ & $4.370 \mathrm{e}-08$ & 0.7402 & 0.6391 \\
Residuals & 51 & $3.0089 \mathrm{e}-06$ & $5.900 \mathrm{e}-08$ & & \\
& & & & & \\
\hline
\end{tabular}


Table S17: Result statistical test of the P content in the soil (with Anova). Df is degrees of freedom,

770 Sum Sq is sum of squares, Mean Sq is mean sum of squares.

\begin{tabular}{llllll}
\hline & Df & Sum Sq & Mean Sq & F value & P-value \\
\hline Treatment & 7 & 3.7357 & 0.53366 & 50.7854 & $<2.2 \mathrm{e}-\mathbf{1 6}$ \\
Time & 2 & 0.0354 & 0.01769 & 1.6831 & 0.196 \\
Time ${ }^{\star}$ Treatment & 7 & 0.6375 & 0.09108 & 8.6673 & $\mathbf{5 . 7 4 5 e - 0 7}$ \\
Residuals & 51 & 0.5359 & 0.01051 & & \\
\hline
\end{tabular}

771

772 Table S18: Result statistical test of the S content in the soil (with Anova). Df is degrees of freedom,

773 Sum Sq is sum of squares, Mean Sq is mean sum of squares.

\begin{tabular}{llllll}
\hline & Df & Sum Sq & Mean Sq & F value & P-value \\
\hline Treatment & 7 & 121.870 & 17.4100 & 26.7582 & $\mathbf{5 . 5 2 4 e - 1 5}$ \\
Time & 2 & 26.083 & 13.0415 & 20.0440 & $\mathbf{3 . 7 7 4 e - 0 7}$ \\
Time`Treatment & 7 & 2.493 & 0.3561 & 0.5473 & 0.7945 \\
Residuals & 7 & 121.870 & 17.4100 & 26.7582 & $\mathbf{5 . 5 2 4 e - 1 5}$ \\
\hline
\end{tabular}

774

775

776 


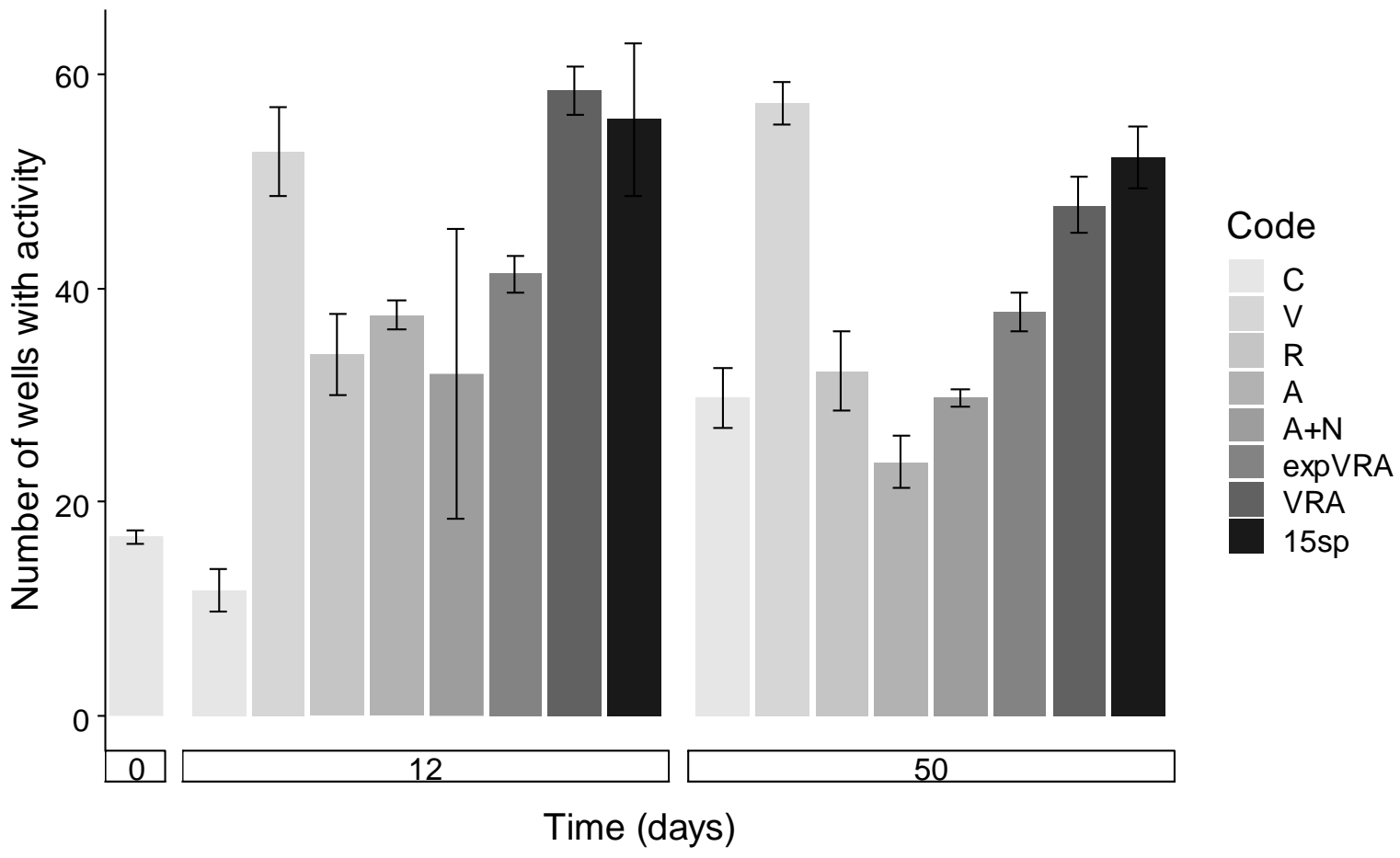

Figure S1: Microbial functional diversity: number of wells that showed a positive response in Biolog ECO plates after incubation of 7 days (mean $\pm S E ; n=4$ ). 

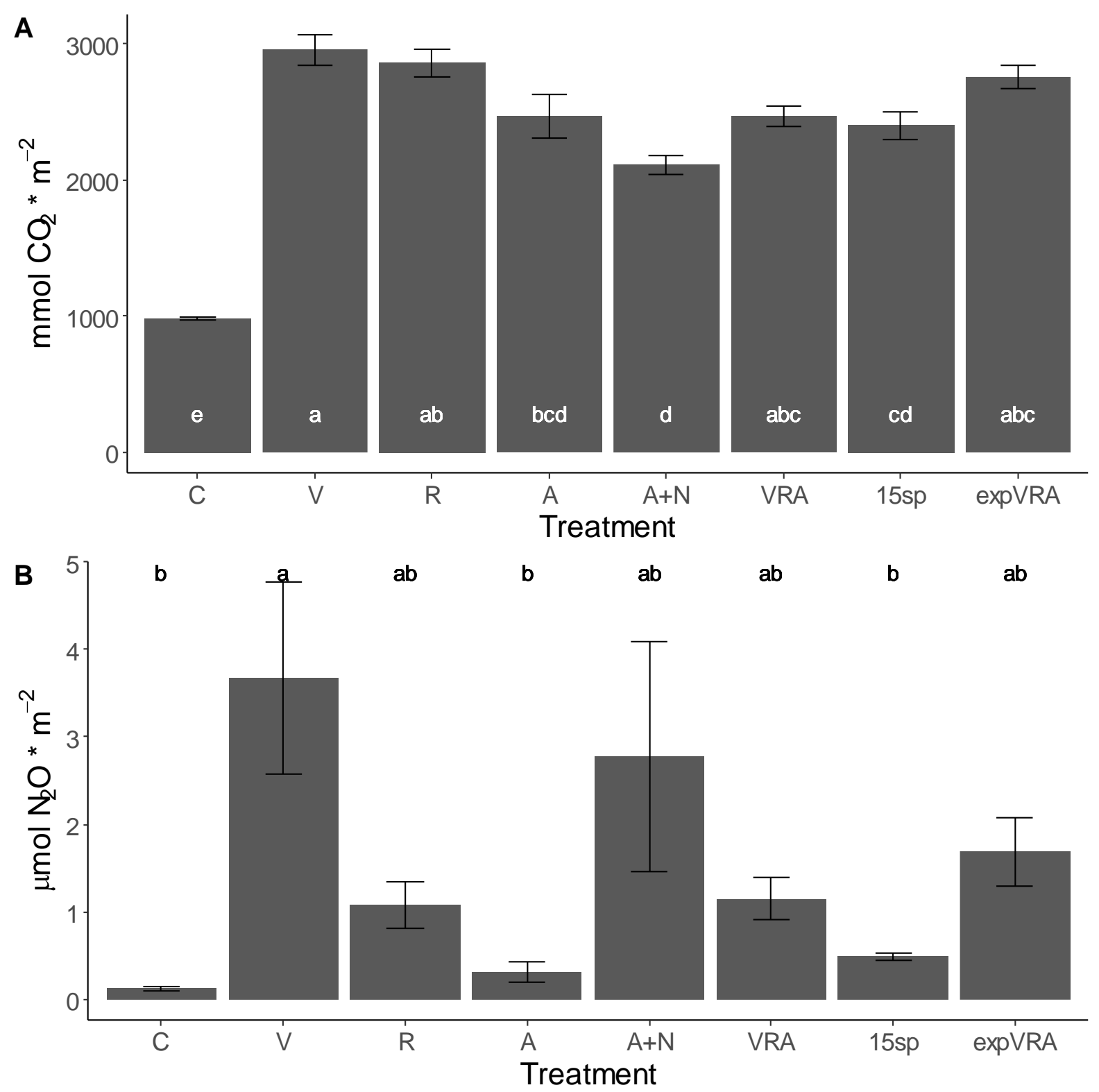

786 Figure S2: Cumulative greenhouse gas fluxes of $\mathrm{CO}_{2}(A)$ and $\mathrm{N}_{2} \mathrm{O}(\mathrm{B})$ (mean $\left.\pm \mathrm{SE} ; \mathrm{n}=4\right)$. The letters 787 indicate significant differences between the treatments. 

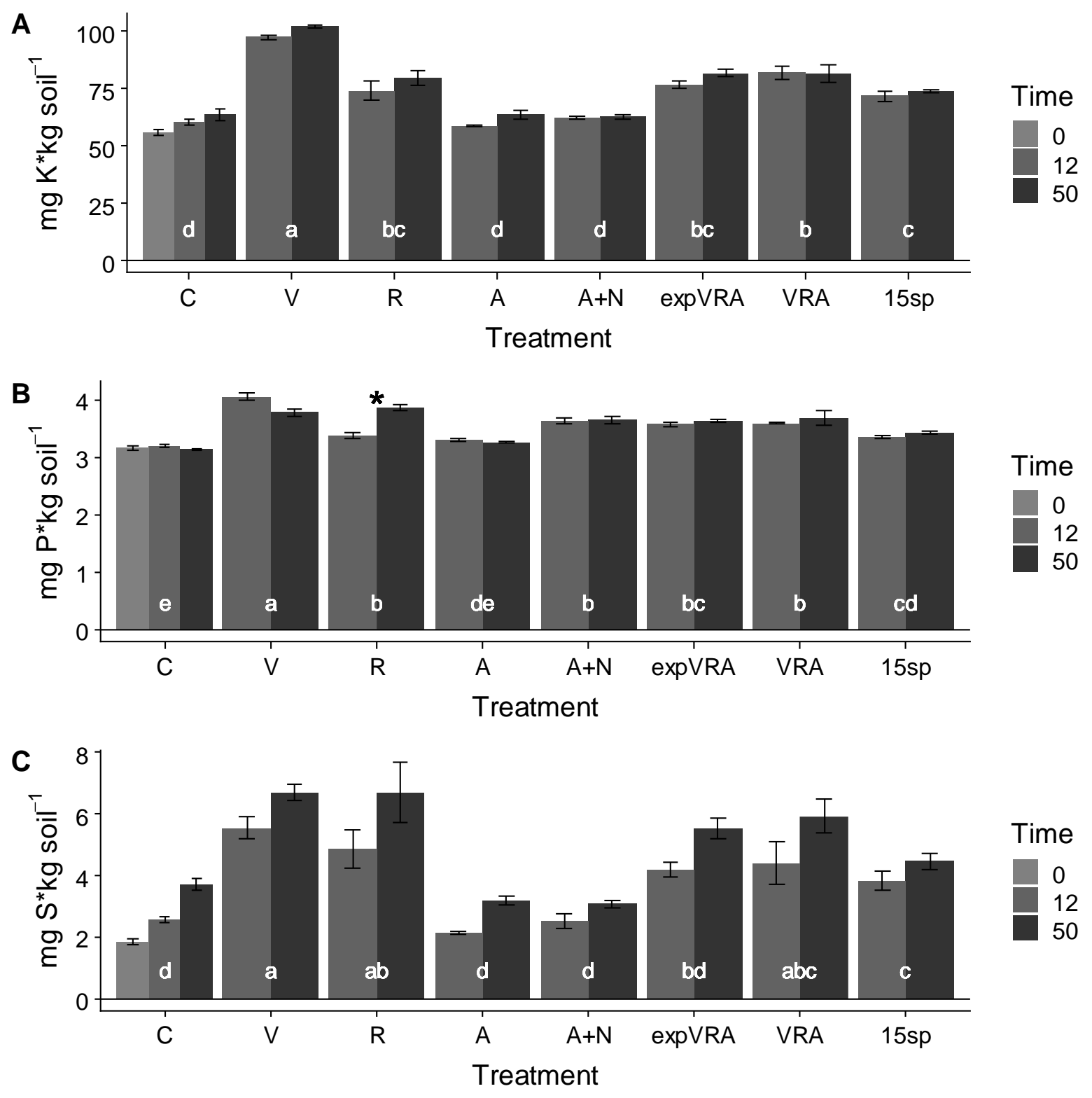

790 Figure S3: Nutrient content (mg per kg of dry soil) in the soil at the different time points (in days)

791 (mean \pm SE; $n=4)$. A: K; B: P; C: S. Letters indicate significant differences between the treatments.

792 The asterisk in B indicate significant difference between T12 and T50 of R. In both A and C, all

793 treatments show similar increase over time. The results of the statistical test are shown in Table S16,

794 Table S17 and Table S18. 


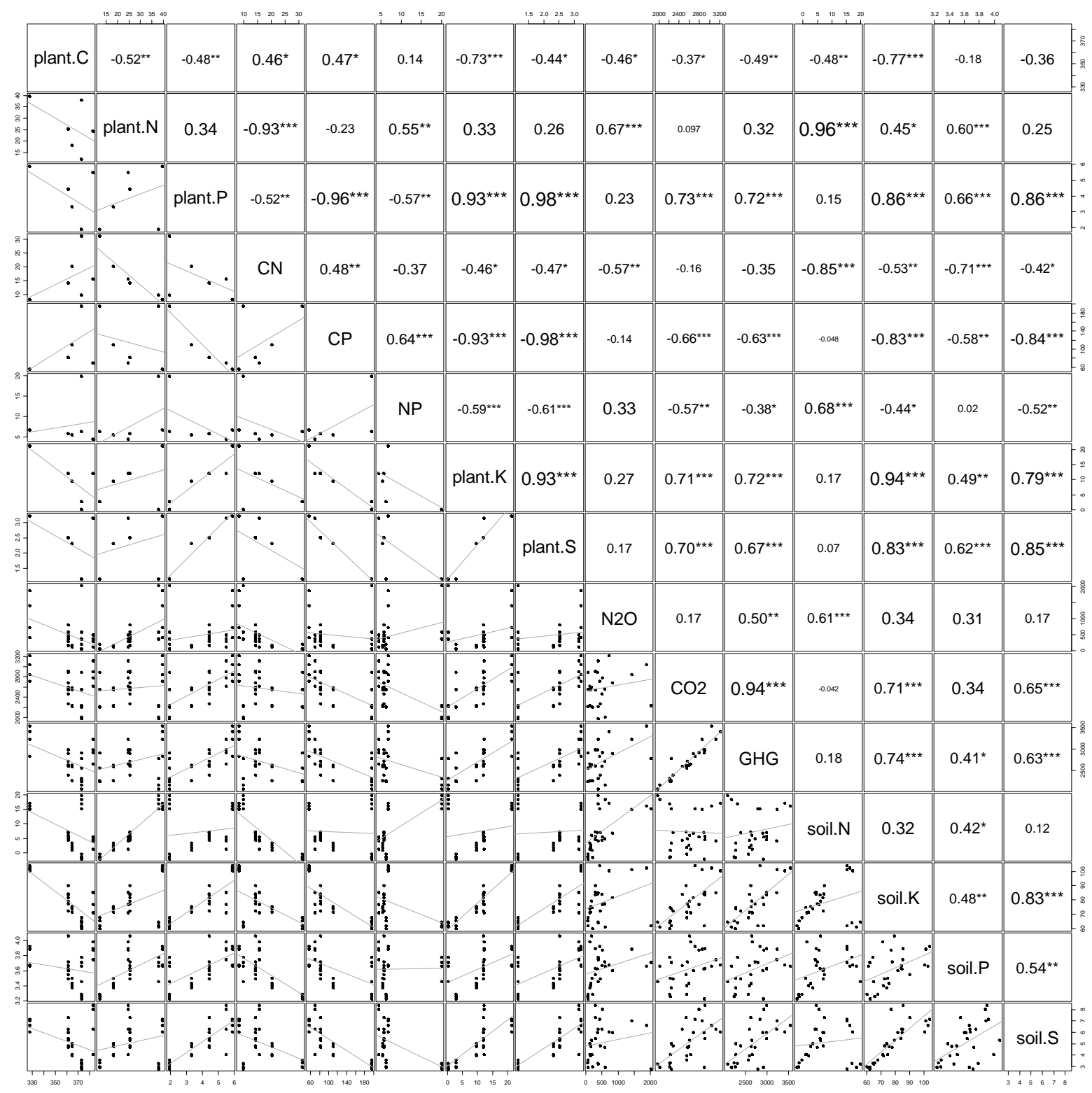

Figure S4: Correlation table between plant residue nutrient content (C, N, P, C:N, C:P, N:P, K and S), cumulative greenhouse gas emissions $\left(\mathrm{N}_{2} \mathrm{O}, \mathrm{CO}_{2}\right.$ and $\mathrm{GHG}$ based on GWP) and soil nutrient content $(\mathrm{N}, \mathrm{K}, \mathrm{P}$ and $\mathrm{S})$ after 50 days of incubation. The numbers in the right panel are the correlation values between the parameters (Pearson correlation). If this correlation is significant, this is shown with asterisks: ${ }^{*}$ if $0.01<p<0.05,{ }^{* *}$ if $0.001<p<0.01$ and ${ }^{* * *}$ if $p<0.001$. The size of the values indicate stronger correlation 